\title{
Are Bankers Worth Their Pay? Evidence from a Talent Measure*
}

\author{
Claire Célérier ${ }^{\dagger} \quad$ Boris Vallée ${ }^{\ddagger}$
}

First Draft: October,14 2010

This Draft: December 15, 2014

\begin{abstract}
We empirically test the hypothesis that relatively high returns to talent explain the wage premium for working in finance. We exploit a specificity of the French educational system to build a precise measure of talent that we match with compensation data obtained from an educational elite. Using this measure, we show wage returns to talent to be three times higher in the finance industry than in the rest of the economy. This greater sensitivity to talent almost fully explains the level of the finance wage premium, its evolution since the 1980s, and, at the individual level, the pay increase workers obtain when joining the finance industry. Finally, talented workers receive a larger share of variable compensation, and even more so in the finance industry.
\end{abstract}

Keywords: Finance, Compensation, Talent, Wage Distribution, Wage Structure, Superstars

JEL codes: G2, G24, J3, J31, M5

${ }^{*}$ We gratefully acknowledge helpful comments and suggestions from Philippe Askenazy, Bruno Biais, Gilbert Cette, Vicente Cunat, Rudiger Fahlenbrach, Thierry Foucault, Francois Geerolf, Mireia Gine (EFA discussant), Vincent Glode, Ulrich Hege, Johan Hombert, Augustin Landier, Arnaud Maurel, Steven Ongena, Evren Ors, Thomas Piketty, Jean-Charles Rochet, John Thanassoulis, David Thesmar, Alexander Wagner and seminar and conference participants at the Toulouse School of Economics, the Paris School of Economics, the University of Mannheim, the Banque de France, the University of Zurich, the European Labor Association conference, the EFA annual meeting, the AFFI annual meeting, the URPP Finreg conference, and the CSEF. Anna Streinbrecher provided excellent research assistance. We are very grateful to IESF and Chantal Darsch for providing data, and we also thank her for all her help and support.

${ }^{\dagger}$ Claire Célérier - University of Zurich, E-mail: claire.celerier@bf.uzh.ch (Contact Author). Claire Célérier acknowledges financial support from the Swiss Finance Institute and URPP-Finreg.

${ }^{\ddagger}$ Boris Vallée - Harvard Business School, Email: bvallee@hbs.edu 


\section{Introduction}

Compensation in the finance industry has been high relative to other sectors since the beginning of the 1980s. Philippon and Reshef (2012), controlling for education and other individual characteristics, find the finance wage premium to be $50 \%$, on average, in 2006. This high level of pay generates adverse public opinion and intense debate among politicians in the wake of the financial crisis. Although the European commission, Basel committee, and the United States and other countries have since implemented or proposed policies that amount to regulating bankers' pay, the source of the finance wage premium continues to spark debate. The premium may result from labor market competition, firms competing for workers and paying them according to their marginal productivity, which is a function of their talent. Conversely, the pay gap with other sectors could result from market failures that lead to rent extraction by finance workers.

Testing the competitive market explanation for the finance premium is difficult because it requires accurately observing and measuring worker talent. A unique advantage of the French educational system is that prospective engineering students are selected solely on the basis of their national ranking in a competitive exam that covers a wide range of subject matters, in both written and oral format. We exploit this rigorous, multi-dimensional selection process to build a measure of talent, which we use to address the research question: Do relatively high returns to talent in the finance industry explain the finance wage premium?

We show returns to talent to be three times higher in the finance industry than in the rest of the economy, and to explain most of the wage gap between the two. Increasing returns to talent also explain the significant growth in bankers' pay since the 1980s. These results point to the competitive market explanation driving the finance premium. We also show that the pay structure of talented workers in finance includes a relatively large share of variable compensation.

High returns to talent may result from three characteristics of the finance industry, namely, intense use of skill-biased technologies, high capital scalability, and competitive labor market conditions. First, used intensively in the finance industry (Philippon and Reshef (2012)), information technologies increase the productivity of talent by acting as 
substitutes in routine, and as complements in non-routine, tasks (Autor et al. (2003)). Second, the dematerialized nature of fund flows facilitates efficient scaling of capital to skill (Berk et al. (2014)), and the integration of world capital markets, coupled with their deregulation since the 1980s, have amplified these scaling effects. Finally, that talent is easily observable and portable across banks facilitates a highly competitive labor market in finance. Taken together, these factors should result in higher returns to talent in a competitive labor market.

We base our talent measure on French engineering schools' selection process for the following reasons. The examination, which incorporates both written and oral sections covering a wide range of subjects, assesses academic, cognitive, and communication skills, and gauges such personality traits as endurance, volition, and ambition. ${ }^{1}$ Two years spent in the highly selective and competitive environment of preparatory schools prior to examination ensures that candidates are highly motivated. The talent constraint is thus binding, and performance is unbiased by personal coaches, exam preparation boot camps, or other support resources that are often used by applicants to U.S. universities. A further element of the suitability of our research set-up is its focus, by virtue of analyzing talent heterogeneity in a highly educated cohort, on the right tail of the population. ${ }^{2}$ We measure talent with the selectivity of the school from which a worker graduates. We complement this school-level measure of talent, and control for school treatment effects, by also considering age at graduation. A student accepted at a top school after only a year of exam training is likely more talented than a student who requires three years of training. We match these talent measures to a detailed compensation survey dataset that covers $7 \%$ of the total population of French graduate engineers.

Our dataset is derived from a comprehensive wage survey conducted by the French Engineering alumni association. The survey, which gathers alumni data from 160 of the 222 French engineering schools, includes detailed information on education, occupation, family situation, industry, firm type and size, and compensation. Because engineering, business and medicine are the only fields that implement a selective access in France, and engineering is the largest of the three, this dataset covers a significant share of the right

\footnotetext{
${ }^{1}$ Ors et al. (2013) exploit this specificity of the French educational system for business schools.

${ }^{2}$ The heterogeneity in talent for the right tail is typically overlooked in population-wide measures like SAT scores.
} 
tail of the skill distribution in that country. Our dataset spans the period from 1983 to 2011. Each of 15 repeated cross-sections covers, on average, 30,800 individuals working in France or abroad. Using this survey data, we confirm French graduate engineers in the finance sector to be better paid, earning, over the period 2004-2011, a premium of 30\%, on average, a premium that has been increasing since the 1980s. This finding is consistent with Philippon and Reshef (2012). In line with Bell and Van Reenen (2014) and Bell and Van Reenen (2013), we also observe a relatively high and increasing skewness in wage distribution in the finance industry.

That returns to talent are relatively high in the finance industry, and that they almost entirely explain the sector's wage premium, are the central results reported in our paper. The main equation regresses the log of yearly gross wage on our talent measure and its interaction with industry dummies. Graduating from a school one notch higher in terms of selectivity induces a $9 \%$ average wage premium in the finance industry, versus a $2.5 \%$ relative premium in the rest of the economy. Controlling for the interaction between our talent measure and the finance sector dummy makes the finance sector fixed effect disappear. Higher returns to talent thus almost fully explain the finance wage premium.

The foregoing result is confirmed when graduation age is used as an alternative measure of talent, thereby allowing all school-level, unobserved variables to be absorbed through school fixed effects. We again find wage returns to talent to be three times higher in the finance industry than in the rest of the economy, and to account for a significant part of the finance premium. This additional analysis rules out school differences in quality of training or intensity of focus on finance as explanations for our main result.

Our result is robust as well to the introduction of individual fixed effects in a pseudopanel regression that estimates the effect on wages of switching to the finance industry from another sector. We track individuals across surveys via detailed socio-demographic variables, such as father's and mother's occupations and years of birth, and educational variables like name of engineering school and type of specialization. The wage premium obtained at switching to the finance industry being fully explained by higher returns to talent, our finding cannot be due to unobserved characteristics at the individual level, such as social background or risk aversion.

We also observe a trend towards increasing returns to talent that accounts for the 
wage premium's evolution over past decades. Estimating our main equation over subperiods reveals wage returns to talent to have increased nearly threefold over the period 1980-2011. Thus, our results shed new light on the wage growth in finance since the 1980s documented in the literature.

Finally, we show the share of variable compensation to be positively correlated with our measure of talent. ${ }^{3}$ Our findings thus point to an interaction between competition for talent and incentives.

We find alternative explanations for the finance wage premium difficult to reconcile with our data. A battery of specific tests rule out talent allocation effects, network effects, compensating wage differential, and individual level time invariant characteristics that are orthogonal to talent as potential drivers for our results.

Our work expands on the recent empirical literature that has identified a high level of compensation in the finance industry relative to the rest of the economy, and high skewness at the top of the wage distribution. Philippon and Reshef (2012), Oyer (2008), and Goldin and Katz (2008) - based on data from the Census Population Survey, a Stanford MBA survey, and Harvard alumni compensation survey, respectively - find the finance premium to vary from $40 \%$ (in Philippon and Reshef (2012)) to more than 100\% (in Oyer (2008) and Goldin and Katz (2008)). Philippon and Reshef (2012) documents the post 1980s increase in compensation in finance relative to the rest of the private sector, after controlling for education, and Kaplan and Rauh (2010) and Bell and Van Reenen (2014) show the financial sector share in top end brackets of the income distribution to have significantly increased. The main contribution of the present paper is to attribute these wage distribution patterns in the finance industry to higher and increasing returns to talent.

Our paper also contributes to the literature that investigates the dramatic growth in top executive pay and earning inequalities observed since the 1980s. This literature includes theories of managerial power (Bebchuk and Fried (2004)), social norms (Piketty and Saez (2006); Levy and Temin (2007)), incentives, and competition for talent or managerial skills (Frydman (2007), Murphy and Zábojník (2004), Gao et al. (2014), Geerolf (2014), Guadalupe (2007)). Our results are consistent with the evolution of wages

\footnotetext{
${ }^{3}$ We calculate the variable wage from a survey question on compensation structure.
} 
reflecting a change in market returns to talent, magnified in recent decades by scale effects (Gabaix and Landier (2008), Kaplan and Rauh (2013), and Greenwood and Scharfstein (2013)) and skill-biased technological change (Katz and Murphy (1992); Garicano and Rossi-Hansberg (2006)).

Our paper also provides new evidence on the interaction between competition for talent and the incentive structure of pay. Lemieux et al. (2009) show wages to be more closely related to worker production in performance-pay than in non-performance-pay jobs, and Cuñat and Guadalupe (2005) show that a higher level of product market competition increases the performance pay sensitivity of compensation schemes. Reliance on incentive pay may be higher for talented workers because of higher monitoring costs (Biais and Landier (2013)), higher productivity of effort, or better outside options (Giannetti and Metzger (2013)), but the causality can also be in the opposite direction; performance pay may be used as a sorting mechanism to attract talented workers (Benabou and Tirole $(2015))$.

Finally, the results reported in this paper raise questions of concerning externalities that might be generated by competition for talent in the finance industry. By offering relatively high wages for the same level of talent, the finance sector may lure talented individuals away from other industries (Baumol (1990) and Murphy et al. (1991) argue that this may have a downward impact on economic growth) or from financial regulation (Shive and Forster (2014), Bond and Glode (2014)). Shu (2013), however, shows the financial industry's talent-capture effects to be limited. Competition for talent can also generate inefficient risk taking (Acharya et al. (2013)), lead to excessive overbids (Glode and Lowery (2013)), increase the fragility of banks (Thanassoulis (2012)), or shift effort away from less contractible tasks, resulting in efficiency loss (Benabou and Tirole (2015)).

The paper proceeds as follows. In Section 2, we develop the theoretical framework for our analysis, and in Section 3, describe how we measure talent. In Section 4, we provide summary statistics for our dataset and assess the representativeness of the sample. We present our results in Section 5, and discuss alternative explanations in Section 6. Section 7 concludes. 


\section{Theoretical Framework}

The role of talent when contracting compensation is largely documented in the literature, beginning with Rosen (1981). ${ }^{4}$ We build on these theoretical insights to develop our research hypothesis: the heterogeneity in the wage distribution observed across sectors comes from sector-specific wage sensitivity to talent.

In a competitive labor market, firms want to retain talented workers who generate large profits. ${ }^{5}$. If the profit sensitivity to talent varies by industry, competition for talent should result in wage returns to talent being heterogeneous across industries. There are three main reasons for profit sensitivity to talent to vary significantly by industry. First, some industries rely more on skill-biased technology, and consequently the relative productivity of skilled workers tends to be higher in these industries (Katz and Murphy (1992), Autor et al. (1998) and Autor et al. (2003)). These technologies increase returns to skills by playing a substitutive role in routine, and complementary role in non routine, tasks. Second, labor market competition varies across industries, and matching talent to tasks is more efficient in competitive labor markets. Competition for talent is highest in industries in which talent is easily observable and industry-general rather than firm specific, making it portable across firms. The third reason has to do with scale effects associated with the productivity of talent. When the scale of a task varies with talent, a small difference in the latter can significantly boost productivity, and, hence, wages. The scale effect is high for jobs in which physical constraints and marginal costs are low (e.g., author or software developer), and low for jobs in which input physical capital is high (e.g., restaurant owner). ${ }^{6}$

All three of the reasons cited above for heightened returns to talent are present in the finance industry. Information technology, from real time databases to powerful in-house

\footnotetext{
${ }^{4}$ See also Sattinger (1993), Terviö (2008), Terviö (2009) and Gabaix and Landier (2008). Lucas (1978) analyzes the impact of talent on the distribution of firms.

${ }^{5}$ An important assumption throughout our study is that, in a competitive labor market, firms adequately internalize in the design of their compensation packages how much expected profit a given worker will generate. Data limitations preclude observation of worker productivity.

${ }^{6}$ Evening class high school teachers in South Korea provide a recent example of talent scalability and its potential impact on wages. Talent has always been key in teaching. The implementation of online technologies that multiply the productivity of talented teachers has generated a shock to teaching scalability and sent some top teachers' wages skyrocketing to as much as seven figures. Source: http://online.wsj.com/article/SB10001424127887324635904578639780253571520.html.
} 
risk management and asset pricing software, is ubiquitous in the finance industry, hence, Philippon and Reshef (2012) finding that the finance industry is information-technology intensive. With respect to observability and portability, worker productivity can be quantified, and low cost observation of individual performance both inside and outside the firm, facilitates efficient job assignment and capital allocation (Berk et al. (2014)). This scalability effect is magnified by the dematerialized nature of financial transactions, and the integration and deregulation of world capital markets since the 1980s. Kaplan and Rauh (2010) estimate that capital per employee in the top U.S. security firms increased from $\$ 124,000$ (in 2004 dollars) in 1972 to $\$ 1,789,000$ in 2004 . They also observe a twentythree-fold increase in capital per managing director since the 1970s. Other sectors, such as law, consulting, and computer technology, exhibit comparable characteristics, albeit to a lesser extent.

The empirical prediction derived from our hypothesis is that wage elasticity to talent should be relatively high in the finance sector. Our paper is, to our knowledge, the first to test this prediction empirically, and measure the share of the finance premium that can be attributed to talent effects.

\section{Measuring Talent}

We use a specificity of the French educational system to build a unique proxy for talent. To earn the official title "graduate engineer", students in France need to graduate from a master program in any field of engineering offered by one of 240 selective small scale institutions. ${ }^{7}$ These so-called "Grandes Ecoles d'Ingénieurs" select students on the basis of their national ranking in a competitive exam. We use this selection process to build a measure of talent for the entire population of engineers.

\subsection{French Engineering Schools' Selection Process}

The national competitive exam on the basis of which French Grandes Ecoles d'Ingénieurs select students for admission includes both written and oral tests. Students' performance

\footnotetext{
${ }^{7}$ Thirty thousand diplomas are awarded annually at the national level.
} 
on this exam reflects strong cognitive and academic skills as well as ambition, motivation, volition, endurance, and ability to work under pressure.

The exam assesses, through written tests covering a wide range of subjects, a large set of formal academic skills, with mathematics, physics, programming, French literature, and a foreign language being among the compulsory topics. Candidates also select an optional topic from among biology, chemistry, engineering, and computer science. More than 80 hours of testing are involved over a three-week period.

A series of complementary 20-minute oral exams test, for an equally wide range of subject matter, presentation, communication, and interaction skills. Candidates solve problems provided to them and present their solutions to one or more professors in interviews.

The process concludes with the assignment of a final national ranking that assures applicants to engineering school a priority position. Students favor reputation over field expertise or location in their selection of schools, and deviations are quite rare, especially for top schools. Admitted students study for three years on campus before being awarded a graduate degree.

Two years are spent preparing for the exam at highly selective institutions, comparable to boarding schools, that select students on the basis of superior academic performance in high school. ${ }^{8}$ Studying at these institutions requires a high motivation and ability to work under pressure. Students are ranked quarterly and eliminated after the first year if their performance is too low (Ors et al. (2013)).

A group of lower rank schools recruit directly after high school based on the results to the French Baccalauréat and therefore offer a five year curriculum. The selection process employed by French engineering schools is summarized in Figure 1.

\section{INSERT FIGURE 1}

\subsection{School Ranking and Talent Measure}

We arrive at a talent measure by classifying engineering schools into ten categories based on selectivity in the competitive exam. Group 1, which enrolls, on average, the most

\footnotetext{
${ }^{8}$ The selection rate in the science and engineering fields is approximately $15 \%$ for those who hold a scientific Baccalauréat. Source: www.data.gouv.fr.
} 
talented students, includes the most selective school, while Group 10 includes the least selective schools.

We compute a school's selection rate by dividing the rank in the national exam of the last admitted student by the total number of enrolled students nationwide. Information on the rank of the marginal student and on the total number of enrolled students is public and available for the period 2002-2012. ${ }^{9,10}$ For prominent schools, namely "Ecole Polytechnique", all "Ecole Centrales", "Mines", "Ponts et Chaussees", "Supelec", "Supaero" and "Telecom Paris", we take the rank of the last admitted student as given. As an example, in 2012, the marginal student in the mathematics option in Ecole Polytechnique is ranked $124^{\text {th }}$, and 8,343 students take the national exam. Hence, the selection rate of Ecole Polytechnique is $1.5 \%$. Because some students self-select and do not apply to the lower ranked schools, the rank of the marginal student for the other schools is biased upward. We therefore adjust the rank of the last admitted students for these schools by adding to the marginal student rank the number of students that do not apply. This calculation therefore assumes that the students that do not apply would be admitted if they do. Back to our example, the rank of the last admitted student in Enac Toulouse in 2012 is $1,645^{\text {th }}$ in the mathematics option. Given that only 7,094 students apply to this school out of a total of 8,343 enrolled students nationwide, the adjusted rank of the last admitted students is $2,894^{\text {th }}=1,645+(8,343-7094)$, which gives a selection rate of $34.7 \%(2894 / 8343)$.

A smaller group of school admit students directly after the Baccalauréat, and not through the national competitive exam following preparatory school. For this subgroup, we measure the selectivity of the Engineering school by using the average Baccalauréat grade of their admitted students. We allocate these schools across groups 7 to 10, where the average Baccalauréat grade of admitted students from other schools is comparable. Schools allocated to group 7 have an average Baccalauréat grade around 16/20, whereas the ones allocated to group 10 are around $12 / 20 .{ }^{11}$

Selection rates for each category are reported in columns (1) and (2) of Table 2.

\footnotetext{
${ }^{9}$ http://www.scei-concours.fr/

${ }^{10}$ We use information from the end of that sample period, as the level of school selectivity is strongly persistent. Our results are robust to using the average over the period.

${ }^{11}$ N.B: our results hold when excluding these schools. (See online appendix for more details.)
} 
The highest category includes the Ecole Polytechnique, which recruits the top $1.5 \%$ of students. The second highest category includes Mines de Paris, Ecole Centrale Paris, and Ecole des Ponts et Chaussées. The lowest category includes mainly schools that admit students directly after high school. Figure 2 plots the admission rate across the different groups of our talent measure.

\section{INSERT FIGURE 2}

Our measure of talent possesses several key advantages. First, it covers, with high comparability owing to consistent ranking, the total population of French engineers since 1980. Second, the measure maps such traits requisite to successful careers as cognitive ability, resistance to stress, and interpersonal skills. Moreover, in terms of prestige, and even pay-off (students from the top school are eligible for stipends), the stakes of the competitive exam are comparable to those associated with professional careers. Third, the homogeneity of the population we analyze enables us to disentangle education and motivation from talent, making our talent measure extremely sensitive. All students have the same level of education and years of schooling, and follow the same educational path (pursued a science major in high school and applied, successfully, to a selective preparatory school). Each student self selects, with respect to personal investment and despite guaranteed admission to a French university in any year following their high school graduation, to sit the toughest of exams. Fourth, our focus on a small fraction of the right tail of the talent distribution makes our talent measure extremely precise compared to population-wide measures such as SAT scores. Lastly, the admission process limits distortions due to networking, social background, reputation, and donations, the written exam being totally anonymous and letters of recommendation not being required.

\subsection{Non School Specific Measure of Talent}

Using age at graduation as an alternative measure enables us to differentiate graduates within each school. In the French educational system, highly performing students, on average, graduate at a relatively early age either because they skip a year or because 
less talented students often repeat years. ${ }^{12}$ Hence, a student who enters the first-ranked engineering school, Ecole Polytechnique, at the age of 19 after two years of preparation will be more talented, on average, than a student who enters the school at age 21 after three years of preparation. Age at graduation, not being school specific, enables us to control for school unobserved variables by introducing school fixed effects. ${ }^{13}$ Figure 3 plots the distribution of graduation age in our sample.

\section{INSERT FIGURE 3}

\section{Data}

\subsection{Survey}

We analyze, empirically, the results of a detailed wage survey consisting of 324,761 observations of engineering school graduates from 1983 to 2011. The survey, conducted by the French Engineering and Scientist Council (IESF), a network of alumni organizations representing 144 of the 240 French engineering schools, or $85 \%$ of the total population of French graduate engineers in 2010, solicits the latest yearly gross wage of each graduate as well as detailed information on demographics, education, careers, job position, and employer. 14,15

We clean the survey data by retaining only respondents between the ages of 20 and 65 who are full time employees and possess a valid industry code and more than one year of experience. ${ }^{16}$ We exclude respondents whose compensation is less than the legal minimum wage, and, for each sector and year, winsorize compensation at the top $1 \%$ of the distribution. ${ }^{17}$ Finally, all nominal quantities are converted into constant 2005 Euros

\footnotetext{
${ }^{12}$ As many as $25 \%$ of students preparing for engineering schools repeat the second year of preparation to improve their results in the competitive exam.

${ }^{13}$ For instance, schools might offer different quality of training or a more specific focus on finance.

${ }^{14}$ http://www.iesf.fr/.

${ }^{15}$ Source: French Education Ministry.

${ }^{16}$ Survey respondents must provide from their latest December pay sheet their yearly gross wage and employer's five digit industry code. Retaining only observations accompanied by a valid industry code ensures that respondents actually consulted their pay sheets, and thereby maximizes the accuracy of wage data and limits measurement errors.

${ }^{17}$ We do not winsorize at the total sample level so that highly paid sectors are not overrepresented in the affected subsample.
} 
using the French National Price Index (IPCN) from INSEE. ${ }^{18}$ These operations leave us with 190,593 observations.

Our analysis benefits from several key features of the IESF survey. Its provision of the name of the engineering school from which each respondent graduated is essential to the implementation of our measure of talent. Its access to unique wage data, including information on its variable share is key to our analysis. Finally, the substantial information the survey provides on demographics, job position, employers, and work location (including engineers working outside of France, in London, for example, or New York) enables our analysis to control for a broad set of variables.

\subsection{Summary Statistics}

\section{INSERT TABLE 1}

Table 1 provides key variable summary statistics together with information on the scope of the survey. Frequency has increased from every five years from 1983 to 1986 to every year from 2004 onwards. The number of respondents per survey averaging 23,000, each survey represents, on average, $6.9 \%$ of the total population of French engineers. The response rate is $18.8 \%{ }^{19,20}$

Wage distribution among French graduate engineers has become increasingly scattered over the past three decades. Whereas the average wage, in constant euros, decreased slightly, from 63,000 euros in the 1980s to 58,000 euros in the 2000s due to composition effects, wages at the 99 th percentile increased by more than $14 \%$ over the same period. ${ }^{21}$ This result is in line with recent literature showing inequality to have increased in most OECD countries, mainly at the very top of the wage distribution (Piketty and Saez (2003); Piketty and Saez (2006)).

\footnotetext{
${ }^{18}$ Data is available at http://www.imf.org/external/datamapper/index.php.

${ }^{19}$ Although response is voluntary and the survey sent only to alumni whose names and addresses are known to the association, selection effects are likely to be low. First, median gross wage including bonuses in the 2009 survey is similar to that computed for the same population in a 2009 survey of French companies conducted by Towers Perrin, a leading compensation consulting company. Second, respondent demographics are similar to those obtained by the French National Statistical Institute (INSEE) in the French Employment Survey, for which the sample is randomly selected.

${ }^{20}$ The IESF mailed the survey until 2000, and has e-mailed it since 2002.

${ }^{21}$ The slight decrease is due mainly to the decrease in the age of the average respondent.
} 
We define 48 industries based on the official industry classification codes respondents provided for their employers. Table 1 details the percentage share of respondents in the highest-paying industries (i.e., finance, oil, chemical, and consulting). Finance accounts for approximately $2 \%$ of the total sample. ${ }^{22}$

Table 1 also includes summary statistics on demographics, jobs, careers, employer, work location, and compensation structure. A decrease in respondents' average age is likely driven by the change to an e-survey format. The increase in the share of women respondents is in line with how the composition of engineer population has evolved nationwide. The share of respondents working outside France has dramatically increased, which is consistent with the improved mobility of highly qualified workers. (See the online appendix for a list of the questions asked in the 2000 survey.)

\subsection{The Talent Measure}

Table 2 reports the selection rate, number of schools and students, and summary statistics for individual characteristics by talent category. By construction (of our talent measure), a larger number of respondents is associated with the lower level of talent. Columns (6) and (7) show wage level and share of top managers to increase with talent. From column (8), which reports, by talent category, the share of respondents that graduated at least one year earlier than the standard age, age at graduation appears to be highly correlated with talent category. Its focus on a highly educated population notwithstanding, our sample offers considerable heterogeneity with respect to talent and wages.

\section{INSERT TABLE 2}

\subsection{Representativeness of the Sample}

We compare the patterns of compensation in the finance industry observed in our data to the ones found in the literature.

Graphical evidence of the evolution of the wage distribution is provided by Figure 4, which plots the evolution of the coefficient of the finance sector dummy in quantile

\footnotetext{
${ }^{22}$ See the online appendix for a detailed list of, and the distribution of workers across, all industries.
} 
regressions estimated at the $10^{\text {th }}, 50^{\text {th }}$, and $90^{\text {th }}$ percentiles in 1982 and 2006 . Skewness in wages appears to have increased significantly over past decades. ${ }^{23}$

\section{INSERT FIGURE 4}

We confirm this observation by estimating the annual wage premia in the finance industry via the following equation,

$$
w_{i, t}=\epsilon \times \text { Talent }_{i}+\beta \times I_{i}+\gamma \times X_{i}+\mu \times D_{t}+\lambda_{i, t}
$$

where $w_{i, t}$ is the log yearly gross wage, Talent is the talent measure, $I_{i, t}$ represents the vector of industry dummies, $D_{t}$ the vector of year dummies, $X_{i, t}$ is a vector of individual characteristics, and $\epsilon$ represents the average returns to talent in the economy. ${ }^{24}$ This estimation controls for our talent measure, as well as for demographic, occupation, job, and employer characteristics. ${ }^{25,26}$

Results are displayed in column (1) of Table 3. The average wage premium in finance over the $1983-2011$ period in our sample is $24 \%$, compared to $13 \%, 12 \%$, and $7 \%$ in the next best paying industries, consulting, oil and chemistry, respectively. Our finding that finance industry workers are the best paid is consistent with results reported by Philippon and Reshef (2012), Oyer (2008), Goldin and Katz (2008). That our estimation of the finance wage premium is in the lower range of recent estimations in the literature is likely due to our rich set of controls, most importantly our talent measure, and the educational homogeneity of our sample.

\footnotetext{
${ }^{23}$ See the online appendix for further discussion of the evolution of wages at the $10^{\text {th }}, 50^{\text {th }}$, and $90^{\text {th }}$ percentiles of the earnings distribution in the finance, oil, chemistry, and consulting industries.

${ }^{24}$ For purposes of clarity, and so that it is increasing with worker skill, Talent is defined in our main measure as 10 minus the rank of the school from which a respondent graduated.

${ }^{25}$ Acemoglu and Autor provide evidence of the strong explanatory power of occupational categories in wage regression.

${ }^{26}$ Demographic controls include years of experience, experience squared, experience cubed, gender, marital status, and gender $\times$ marital status. We control for occupation with nine dummies (for production, logistics, development, IT, commercialization, administration, executive, education, and for employer type with five dummies (self-employment, private sector, state-owned company, public administration, and others (e.g., non-governmental organizations)), and for firm size with four dummies (fewer than 20 , from 20 to 500 , from 500 to 2,000, and more than 2,000, employees). Job characteristics are represented by an "Ile de France" dummy (Paris area), a working abroad dummy (as well as country dummies for the United States, United Kingdom, Germany, Switzerland, Luxembourg, China, and Belgium from 2004), and four hierarchical responsibility dummies from no hierarchical responsibility to chief executive.
} 


\section{INSERT TABLE 3}

The external validity of our sample is further supported by Table A2 in the appendix, which replicates Table 6 from Bell and Van Reenen (2014). The first column of Table A2 of the appendix shows the premium to have increased from $7 \%$ to more than $30 \%$, on average, since 2004, and to have been much higher at the $90^{\text {th }}$ than at the $10^{\text {th }}$ and $50^{\text {th }}$ percentiles of the wage distribution. The last row of the table shows the average annualized increase in the premia to be more than $2.8 \%$ at the $90^{\text {th }}$, less than $0.7 \%$ at the $50^{\text {th }}$, and $0.3 \%$ at the $10^{\text {th }}$, percentile. Our finding that the finance wage premium has increased dramatically since the 1980s, and is concentrated among top earners, is again consistent with Philippon and Reshef (2012) and Bell and Van Reenen (2014).

\section{Results}

\subsection{Heterogeneous Returns to Talent across Industries}

We report here our central result, that higher returns to talent in the finance industry explain almost entirely both the sector's wage premium and the skewness of the wage distribution.

Graphical evidence of this result is provided in Figure 5, which plots respondents' predicted wage by industry over the ten categories of our talent measure. We calculate the predicted wages by regressing wages over talent category fixed effects, controlling for demographic and occupational characteristics. We observe wages to be an increasing function of talent, and the magnitude of this relationship to be significantly higher in the finance industry than in other sectors. For example, wages increase from the bottom to the top of the talent distribution in the finance industry by more than $64 \%$ and in the oil industry by only $35 \%$. The relationship between our talent measure and wages in finance appear to be convex.

\section{INSERT FIGURE 5}

We specifically test whether industry-specific wage elasticity to talent can explain the cross-section of wages by including interactions between talent and each industry 
dummies in equation (1),

$$
w_{i, t}=\epsilon \times \text { Talent }_{i}+\beta \times I_{i}+\bar{\epsilon} \times I_{i} \times \text { Talent }_{i}+\gamma \times X_{i}+\mu \times D_{t}+\lambda_{i, t}
$$

where $\bar{\epsilon}$ is the industry specific component of returns to talent (other variables are the same as in equation (1)).

Column (2) of Table 3 reports the results. The positive and significant coefficient of the interaction term between the finance dummy and talent measure shows returns to talent to be significantly higher, three times higher, in fact, in the finance industry than in the rest of the economy. Moving one notch up our talent scale yields a $7.7 \%$ increase in wages for a finance worker, vs. $2.5 \%$ for a worker in the rest of the economy. The consulting industry, consistent with its high talent scalability, offers returns to talent twice as high as in the rest of the economy. Conversely, returns to talent are significantly lower in the oil and chemistry industries than in the rest of the economy likely because of strong physical constraints that limit the scalability of talent in those sectors.

High returns to talent in the finance industry almost entirely explain the finance wage premium. When we include the interaction term $I_{i} \times$ Talent $_{i, t}$ in our specification, the finance premium almost disappears, at $2.3 \%$ (column 2). This result is strongly supportive of talent effects driving the finance wage premium.

\subsection{Controlling for School Fixed Effects}

Our result is robust to including school fixed effects, which is possible when using graduation age as a measure of talent. Column (3) of Table 3 reports the regression coefficients when we interact age at graduation as a talent measure with our industry dummies. We find among alumni from the same school that those who graduate earlier in life are paid relatively more, and that this effect is significantly stronger in finance. Consistent with our previous result, we also find the coefficient on the finance sector dummy to decrease, albeit less than in our main specification, likely due to this talent measure being less granular. This result suggests that treatment effects during school cannot explain our previous findings, and is consistent with the view widely held in France that most of the training occurs during the two years of hard work leading to the selection exam, rather 
than what is taught at the schools themselves.

\subsection{Controlling for Individual Fixed Effects}

We confirm our result by running regressions that include individual fixed effects. Returns to talent almost fully explains the wage increase when a worker switches to the financial sector.

To include individual fixed effects, we convert our repeated cross-section data to a pseudo-panel. We identify unique individuals across time using six socio-demographic variables: year of birth, sex, name of the engineering school, type of specialization and, most important, father's and mother's occupations. The pseudo-panel covers the 20002010 period and contains 15,256 uniquely identified individuals.

We identify the impact of switching sectors on wages using the following regression,

$$
w_{i, t}=\alpha_{i}+\beta \times I_{i, t}+\mu \times D_{t}+\lambda_{i, t}
$$

where $\alpha_{i}$ represents the vector of individual fixed effects, $I_{i}$ is a dummy equal to 1 when a worker joins a given sector, and $D_{t}$ is the vector of year dummies. Results are reported in column (4) of Table 3 . The $27 \%$ wage increase enjoyed by a worker who enters the finance industry is significantly larger than that realized by workers who enter other sectors.

To test whether elasticity to talent explains the potential wage gain from joining finance, we include the interaction of the industry dummy with talent:

$$
w_{i, t}=\alpha_{i}+\beta \times I_{i, t}+\bar{\epsilon} \times I_{i, t} \times \text { Talent }_{i}+\mu \times D_{t}+\lambda_{i, t}
$$

Column (5) of Table 3 displays the result for this specification. We find talent to almost fully explain the wage increase realized by a worker who joins the finance industry, only 2 percentage points of the wage increase not being explained by the interaction term. Elasticity to talent is significantly higher in finance than in other sectors. Conversely, talent is a poor predictor of the pay increase realized by workers who join other wellpaying industries. This result is further evidence that returns to talent are higher in finance, even when all unobservable individual characteristics are absorbed. 


\subsection{Increasing Returns to Talent in the Finance Industry}

That returns to talent have increased over the years provides an explanation for the increase in the finance premium since the 1980s, as documented by Philippon and Reshef (2012).

Columns (1), (2), and (3) of Table 4 report the OLS coefficients of equation (1) over three periods: the 1980s, the 1990s, and the 2000s. We find the coefficient on the interaction term between talent and the finance industry dummy to have increased more than twofold. In the 1980s, one notch in our talent scale translated to an average $2.3 \%$ increase in wages, compared to a $3.4 \%$ increase in the finance industry (column (1)). In the $2000 \mathrm{~s}$, the same difference in talent generates a $9 \%$ increase in wages in finance, compared to a stable $2.6 \%$ increase in the economy at large (column (3)). The residual of the finance premium, measured by the finance sector dummy, remains stable over the different periods (columns (1) to (3)). Returns to talent thus explain both the cross-section and time-series of the finance wage premium.

\section{INSERT TABLE 4}

We also show that returns to talent are increasing with talent. From columns (3) to (5) of Table 6, which divide schools into three groups depending on level of selectivity, we observe returns to talent to be higher in top schools, suggesting either that talent distribution is fat-tailed, or that returns to talent are convex. Returns to talent within each subsample are, however, higher in finance than in the rest of the economy. ${ }^{27}$

\subsection{Competition for Talent and Incentives}

We next investigate whether talent effects influence the structure of pay. Competition for talent may amplify the use of incentive pay by increasing either the cost of incentivizing or the need for retention mechanisms. Incentive costs may be higher when competition for talent is high because talented workers have better outside options or because the productivity of effort is higher when worker assignment to a job is more efficient. The need for retention mechanisms, on the other hand, may induce firms to use performance

\footnotetext{
${ }^{27}$ We further observe that if $19.3 \%$ of CAC40 firms are managed by a CEO who graduated from Ecole Polytechnique, the rate is only $17 \%$ for the finance industry.
} 
pay as a sorting mechanism for attracting talented workers (Benabou and Tirole (2015)). We show incentives and competition for talent to be closely related; a higher level of talent is associated with a larger share of variable compensation, and this is more evident in sectors in which returns to talent are high.

Our analysis of variable compensation utilizes a specific question of the IESF survey. From the year 2000 survey onwards, respondents report the percentage of total compensation that is variable. Bonuses and firm specific incentive schemes are included, stock-options excluded. Variable compensation is confirmed to be a key component of wages in the finance industry, present in $65 \%$ of the compensation packages in finance, vs $41 \%$ in the rest of the economy.

We test whether our talent measure can also explain the level and share of variable compensation in the finance industry. Columns (1) and (2) in Table 5 confirm the validity of our main result regarding total compensation for the subsample of respondents who answered the question on variable compensation. Column (3) documents that variable compensation represents a significantly larger share of total wages in finance than in other sectors. Regressing the share of variable compensation on both the finance indicator variable and the interaction between talent and the finance sector, we observe that more talented workers in finance receive a larger share of variable compensation than workers from the same sector with a lower level of talent. The coefficient on the finance dummy in column (3) is divided by four when we interact this variable with talent in column (4). These results are consistent with the hypothesis that competition for talent affects not only the level, but also the structure, of pay.

\section{Alternative Hypotheses}

This section discusses alternative explanations for the wage premium in the finance industry.

\subsection{Talent Allocation}

The high returns to talent observed in the finance industry may be driven not by compensation for talent, but by the selection of talented people into the highest paying jobs 
in the industry. Some job titles in the finance industry, such as trader, pay much higher, on average, than other jobs. Our results could be driven by some schools preempting the highest paying roles independent of individual talent. This allocation pattern may derive from schools' field specialized training.

We test this possibility by introducing exact job title fixed effects in equation (5), while restricting the sample to finance workers only. This enables us to compare, for the same role (e.g., trader), the wages of the alumni of top and lower ranked schools. ${ }^{28,29}$ Our main result is robust to this additional test. Column (1) in Table 6 reports the returns to talent for the subsample of individuals for which the job title is indicated. Controlling for job titles in column (2), we still find returns to talent to be more than twice as high in the finance industry as in the rest of the economy, and close to the level found in column (2) of table 3.

\section{INSERT TABLE 6}

\subsection{Network Effects}

Our results could be driven by network, rather than talent, effects, in which case the return to school ranking observed would be explained by the quality, size, or reach of an alumni network. In fact, students in high ranking schools are likely to benefit from strong alumni networks and social connections, independent of their talent. A recent literature on networks insists on their importance in such labor market processes as hiring, promotion, and setting compensation (Butler and Gurun (2012), Engelberg et al. (2013) and Shue (2013)).

France's Ecole Polytechnique and related schools are likely to exert the greatest network effects, and, indeed, graduates of these schools are over-represented among top executives and CEOs (Kramarz and Thesmar (2013), Ravanel (2013)). To rule out network effects as the dominant mechanism at play, we exclude these schools from our sample. ${ }^{30}$ Column (6) in Table 6 shows returns to talent in the finance industry to remain signif-

\footnotetext{
${ }^{28}$ Respondents are asked on the 2006-2010 surveys to give their job titles.

${ }^{29}$ Frequencies of answers for workers in the finance industry are provided in the online appendix.

${ }^{30}$ The excluded schools are Ecole Polytechnique, Mines de Paris, Ecole des Ponts, Supelec, AgroParisTech Grignon, Supaero, INP-ENSEEIHT, Supoptic Orsay, ESPCI Paris, and Chimie Paris et Telecom Paris. Centrale Paris is excluded as well, its level of recruitment being equivalent.
} 
icantly positive, hence, our results are not driven only by powerful networks associated with the top schools.

A second test controls for the size of alumni networks, using as a proxy the number of students graduated annually. If this dimension is driving our results, including this control should absorb most of the talent effect in our regressions. Results are displayed in column (7) of Table 6 . We find returns to networks to be higher in the finance industry than in the rest of the economy. Returns to network size do not, however, affect our result with respect to higher wage returns to talent in finance, which remain three times higher in finance than in the rest of the economy and dominate network effects.

As an additional test, we interact our talent variable with an indicator variable for working outside of France, the rationale being that networks of French engineering schools are likely to have significantly weaker effects abroad. The significant and positive coefficient on the triple interaction term between finance, talent, and working outside of France, in column (8), shows returns to talent to be even higher for graduates who work outside of France. This result is supportive of networks effect not playing an important role in returns to talent. In the United States and United Kingdom, which capture more than $50 \%$ of graduates outside France, the labor market is less rigid and therefore likely more competitive than France's, which may explain the higher coefficient.

Finally, social background might be correlated with our talent measure. When we run an additional test that interacts the finance indicator variable with indicator variables for parent job categories, however, our results are unchanged. ${ }^{31,32}$

\subsection{Compensating Wage Differential}

A final alternative explanation would be that because they work relatively harder, and their health or employment are more at risk, more talented individuals deserve a higher compensating differential.

Using data on job satisfaction and hours worked, and controlling for both stress and excessive workload in equation (5), we conduct a battery of additional tests. ${ }^{33}$ We use two

\footnotetext{
${ }^{31}$ The survey includes graduate parent profession.

${ }^{32}$ Regression coefficients are provided in the online appendix.

${ }^{33}$ We do not control for stress and excessive workload in our main results, this information not being available for the entire sample.
} 
dummy variables equal to one if a respondent reports suffering from stress and workload, and zero otherwise. We also introduce a variable that indicates whether a respondent works overtime occasionally, 5 to 10 hours, or more than 10 hours. We find no significant downward impact of these variables on talent return in the finance industry premium. Results are reported in the online appendix.

We employ two strategies to control for unemployment risk. We first observe the fraction of layoffs in the total population of French employees per sector as a measure of unemployment risk. ${ }^{34}$ We find a negative correlation between wages and industry unemployment risk, that unemployment risk has been constant in the financial sector since 1999 (layoff rate $=1.7 \%$ ), and that the finance sector has one of the lowest layoff rates (whole economy average $=2.9 \%$ ). Using as an alternative control a survey question that asks if interviewees experience low job security leaves our main result unchanged.

\section{Conclusion}

The main contribution of this paper is to show that high and increasing returns to talent in finance explain both the distribution and evolution of bankers' pay. To estimate returns requires an appropriate measure of talent. We exploit for this purpose the results of a competitive examination among equally highly educated and motivated candidates.

We apply our talent measure to a unique dataset derived from a compensation survey of the population of French graduate engineers that includes detailed information on wages, exam performance, career, and demographics. In line with the existing literature investigating wages in the finance industry, we find the level of wages in finance to be high and positively skewed, and these patterns to have increased since the 1980s.

Our results raise questions concerning the possible negative externalities that competition for talent in the finance industry might generate. High returns to talent may lure talented individuals away from other industries or from regulation (Shive and Forster (2014)), fuel excessively high levels of pay (Glode and Lowery (2013)), exacerbate bank

\footnotetext{
${ }^{34}$ Source: 2009 labor turnover data from the French Ministry of Labor, Employment and Health. http://travail-emploi.gouv.fr/etudes-recherches-statistiques-de,76/statistiques,78/emploi,82/lesmouvements-de-main-d-oeuvre,272/les-donnees-sur-les-mouvements-de,2268/les-donnees-sur-lesmouvements-de,2633.html
} 
fragility (Thanassoulis (2012)), or induce inefficient risk-taking (Acharya et al. (2013)). An additional question is whether banks correctly internalize the productivity of workers, for instance by taking into account long-term risks. 


\section{References}

Acharya, V., M. Pagano, and P. Volpin (2013). Seeking Alpha: Excess Risk Taking and Competition for Managerial Talent. NBER Working Paper Series (18891).

Autor, D., L. F. Katz, and A. Krueger (1998). Computing Inequality: Have Computers Changed the Labor Market? Quarterly Journal of Economics 113(4), 1169-1213.

Autor, D., F. Levy, and R. Murnane (2003). The Skill Content of Recent Technological Change: An Empirical Exploration. Quartlerly Journal of Economics 118(4), 12791333.

Baumol, W. J. (1990). Entrepreneurship: Productive, Unproductive, and Destructive. Journal of Political Economy 98(5), 893-921.

Bebchuk, L. and J. Fried (2004). Pay Without Performance: The Unfulfilled Promise of Executive Compensation. Harvard University Press.

Bell, B. and J. Van Reenen (2013). Extreme Wage Inequality: Pay at the Very Top. American Economic Review: Papers and Proceedings 103(3), 153-157.

Bell, B. and J. Van Reenen (2014). Bankers and Their Bonuses. Economic Journal 124(574), F1-F21.

Benabou, R. and J. Tirole (forthcoming, 2015). Bonus Culture: Competitive Pay, Screening, and Multitasking. Journal of Political Economy.

Berk, J. B., J. Van Binsbergen, and L. Binying (2014). Matching Capital and Labor. Working Paper.

Biais, B. and A. Landier (2013). The (ir) resistible rise of agency rents. Working Paper, Toulouse School of Economics.

Bond, P. and V. Glode (2014). The Labor Market for Bankers and Regulators. Review of Financial Studies 27(9), 2539-2579.

Butler, A. W. and U. G. Gurun (2012). Educational Networks, Mutual Fund Voting Patterns, and CEO Compensation. Review of Financial Studies 25(8), 2533-2562. 
Cuñat, V. and M. Guadalupe (2005). How does product market competition shape incentive contracts? Journal of the European Economic Association 3(5), 1058-1082.

Engelberg, J., P. Gao, and C. A. Parsons (2013). The Price of a CEO's Rolodex. Review of Financial Studies 26(1), 79-114.

Frydman, C. (2007). Rising Through the Ranks. The Evolution of the Market for Corporate Executives, 1936-2003. Working Paper.

Gabaix, X. and A. Landier (2008). Why Has CEO Pay Increased so Much? Quarterly Journal of Economics 123(1), 49-100.

Gao, H., J. Luo, and T. Tang (2014). Labor Market Competition, Executive Job-Hopping, and Compensation. Working Paper.

Garicano, L. and E. Rossi-Hansberg (2006). Organization and Inequality in a Knowledge Economy. Quarterly Journal of Economics 121(4), 1383-1435.

Geerolf, F. (2014). A Static and Microfounded Theory of Zipf's Law for Firms and of the Top Labor Income Distribution. Working Paper.

Giannetti, M. and D. Metzger (2013). Compensation and Competition for Talent: Talent Scarcity or Incentives? Working Paper.

Glode, V. and R. Lowery (2013). Informed Trading and High Compensation in Finance. Working Paper.

Goldin, C. and L. Katz (2008). Transitions: Career and Family Life Cycles in the Educational Elite. American Economic Review: Papers $\&$ Proceedings 98(2), 363-369.

Greenwood, R. and D. Scharfstein (2013). The Growth of Finance. Journal of Economic Perspectives 27(2), 3-28.

Guadalupe, M. (2007). Product Market Competition, Returns to Skill, and Wage Inequality. Journal of Labor Economics 25(3), 439-474.

Kaplan, S. and J. D. Rauh (2010). Wall Street and Main Street: What Contributes to the Rise in the Highest Income? Review of Financial Studies 23(3), 1004-1050. 
Kaplan, S. N. and J. D. Rauh (2013). Family, Education, and Sources of Wealth among the Richest Americans, 1982-2012. American Economic Review 103(3), 158-62.

Katz, L. F. and K. M. Murphy (1992). Changes in Relative Wages, 1963-1987: Supply and Demand Factors. Quarterly Journal of Economics 107(1), 35-78.

Kramarz, F. and D. Thesmar (2013). Social Networks in the Boardroom. Journal of European Economic Association.

Lemieux, T., W. B. MacLeod, and D. Parent (2009). Performance Pay and Wage Inequality. Quarterly Journal of Economics 124(1), 1-49.

Levy, F. and P. Temin (2007). Inequality and Institutions in 20th Century America. Number 13106.

Lucas, R. E. J. (1978). On the Size Distribution of Business Firms. Bell Journal of Economics, 508-523.

Murphy, K., A. Shleifer, and R. Vishny (1991). The Allocation of Talent: Implications for Growth. Quarterly Journal of Economics 106(2), 503-530.

Murphy, K. J. and J. Zábojník (2004). CEO Pay and Appointments: A Market-Based Explanation for Recent Trends. American Economic Review 94(2), 192-196.

Ors, E., F. Palomino, and E. Peyrache (2013). Performance Gender-Gap: Does Competition Matter? Journal of Labor Economics 31(3), 443-499.

Oyer, P. (2008). The Making of an Investment Banker: Stock Market Shocks, Career Choice, and Lifetime Income. Journal of Finance 63(6), 2601-2628.

Philippon, T. and A. Reshef (2012). Wages and Human Capital in the U.S. Finance Industry: 1909-2006. Quartlery Journal of Economics 127(4), 1551-1609.

Piketty, T. and E. Saez (2003). Income Inequality in the United States, 1913-1998. Quarterly Journal of Economics 118(1), 1-41.

Piketty, T. and E. Saez (2006). The Evolution of Top Incomes: A Historical and International Perspective. American Economic Review 96(2), 200-205. 
Ravanel, M. (2013). Networks Matter at the Top : An Empirical Analysis of French Boardrooms. Working Paper.

Rosen, S. (1981). The Economics of Superstars. American Economic Review 71(5), $845-858$.

Sattinger, M. (1993). Assignment Models of the Distribution of Earnings. Journal of Economic Literature, 831-880.

Shive, S. and M. Forster (2014). The Revolving Door for Financial Regulators. Working Paper.

Shu, P. (2013). Career Choice and Skill Development of MIT Graduates: Are the "Best and Brightest" Going into Finance? Working Paper.

Shue, K. (2013). Executive Networks and Firm Policies: Evidence from the Random Assignment of MBA Peers. Review of Financial Studies 26(6), 1401-1442.

Terviö, M. (2008). The Difference that Ceos Make: An Assignment Model Approach. American Economic Review 98(3), 642-668.

Terviö, M. (2009). Superstars and Mediocrity: Market Failures in the Discovery of Talent. Review of Economic Studies 72(2), 829-850.

Thanassoulis, J. (2012). The Case for Intervening in Bankers' Pay. Journal of Finance 67(3), 849-895. 


\section{A Figures}

\section{High School - Science Major}

$\Downarrow$

Preparatory School (2 years, Selection rate: $15 \%$ )

\begin{tabular}{lcc}
\hline Subject & $\begin{array}{c}\text { \# Hours } \\
\text { (per Week) }\end{array}$ & $\begin{array}{c}\text { \# Exams } \\
\text { (per month) }\end{array}$ \\
\hline Mathematics & 12 & 4 \\
Physics and Chemistry & 8 & 2 \\
Industrial Science & 2 & 0 \\
Literature & 2 & 1 \\
Foreign Language & 2 to 4 & 2 \\
Programming & 2 & 0 \\
\hline & $\Downarrow$ &
\end{tabular}

National Competitive Exam

\begin{tabular}{|c|c|c|c|}
\hline \multicolumn{2}{|c|}{ Written Competitive Exam } & \multicolumn{2}{|c|}{ Oral Competitive Exam } \\
\hline Subject & Coefficient & Subject & Coefficient \\
\hline Mathematics 1 & 8 & Mathematics 1 & 16 \\
\hline Mathematics 2 & 7 & Mathematics 2 & 16 \\
\hline Physics & 6 & Physics & 20 \\
\hline Industrial Science & 6 & Industrial Science & 15 \\
\hline Literature & 6 & Literature & 8 \\
\hline Foreign Language & 6 & Foreign Language & 8 \\
\hline \multirow[t]{2}{*}{ Computer Science } & 4 & Chemistry & 9 \\
\hline & & Sport & 5 \\
\hline
\end{tabular}

Final Ranking

Figure 1. Selection Process in French Engineering Schools

Note: This graph summarizes the selection process to enter in French Engineering Schools. 


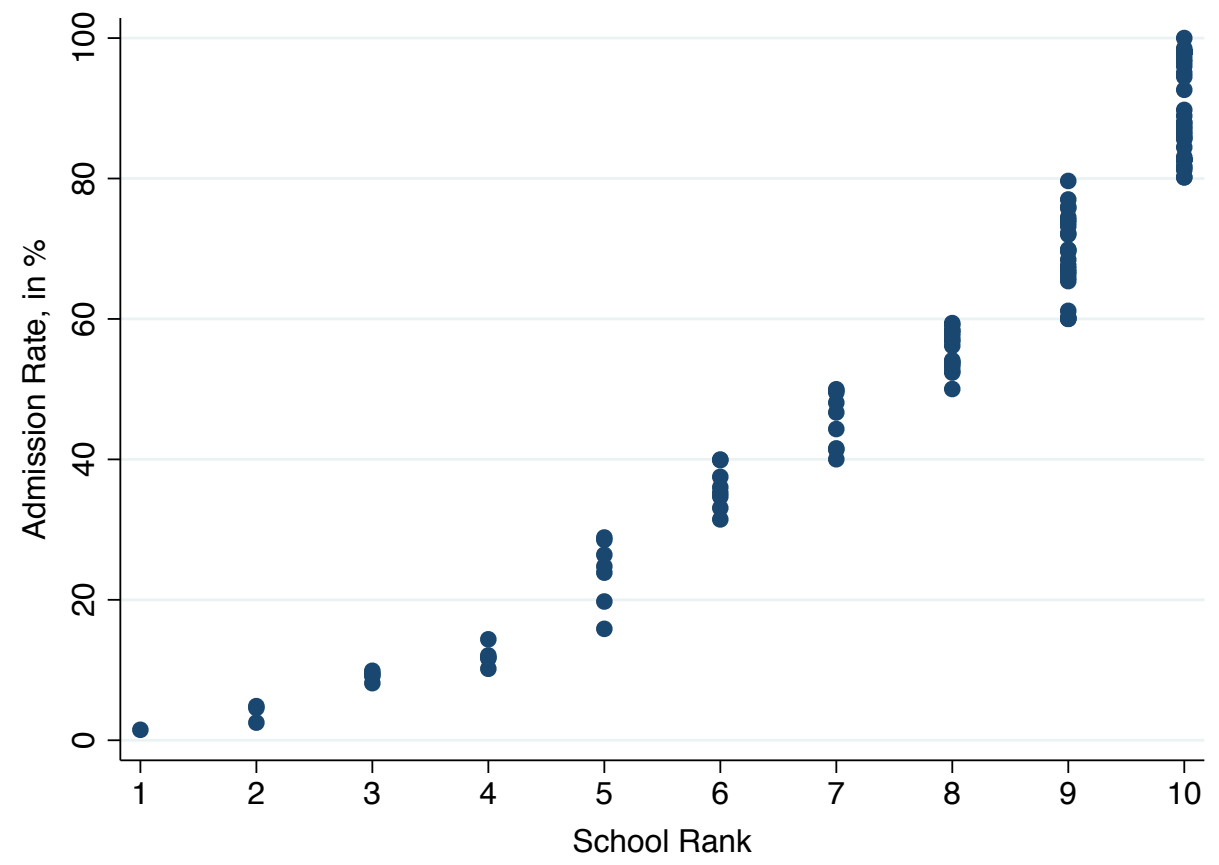

Figure 2. Distribution of Engineering Schools by Admission Rate

Note: This graph displays the distribution of schools by admission rate into the 10 levels of our talent measure. French engineering schools, or "Grandes Ecoles", select students for admission based chiefly on national ranking in a competitive written and oral exam. Schools are sorted on their level of recruitment, measured as the ratio of the marginal student's rank in the national competitive exam to the total number of competing students. 


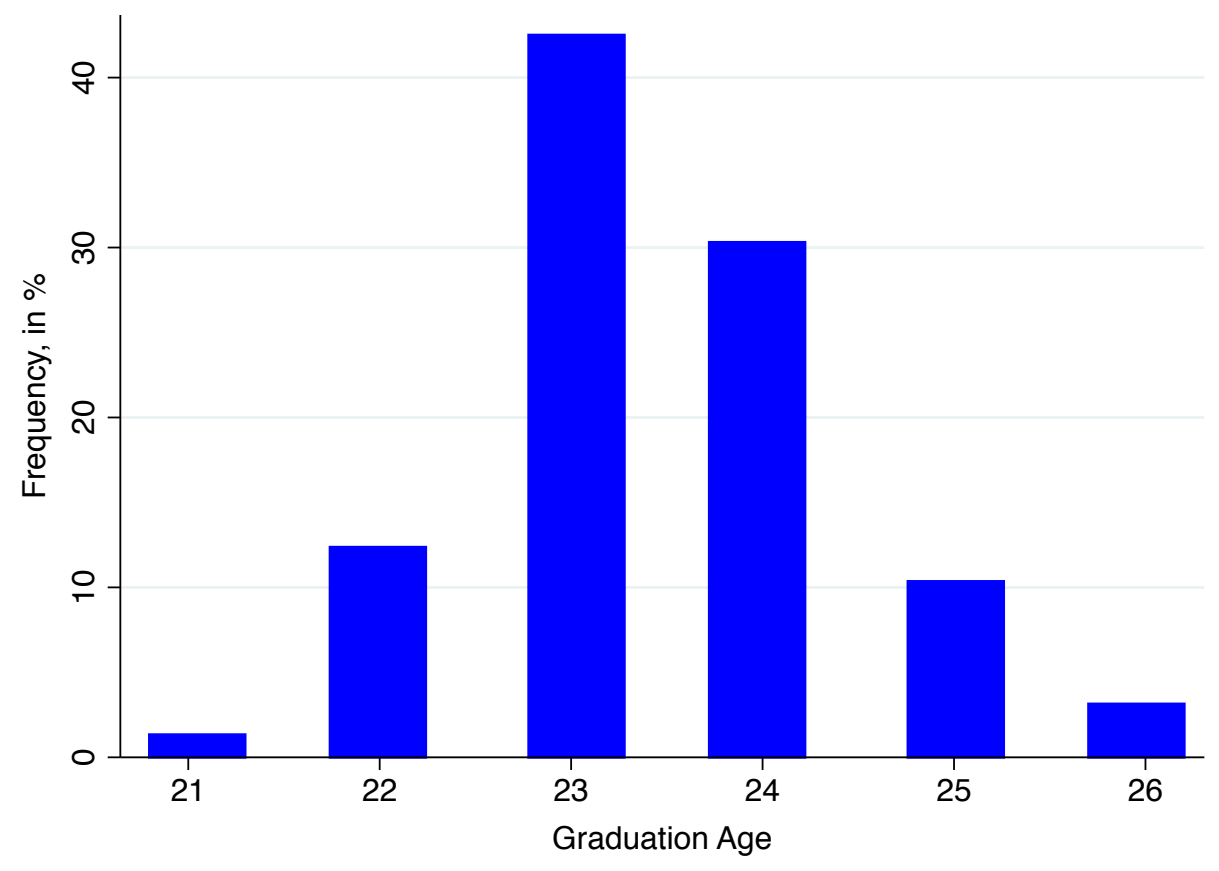

Figure 3. Distribution of Age at Graduation

Note: This figure plots the distribution of graduation age across the survey sample. Heterogeneity results from students both skipping years before high school and repeating years, typically the second year of preparatory class. 


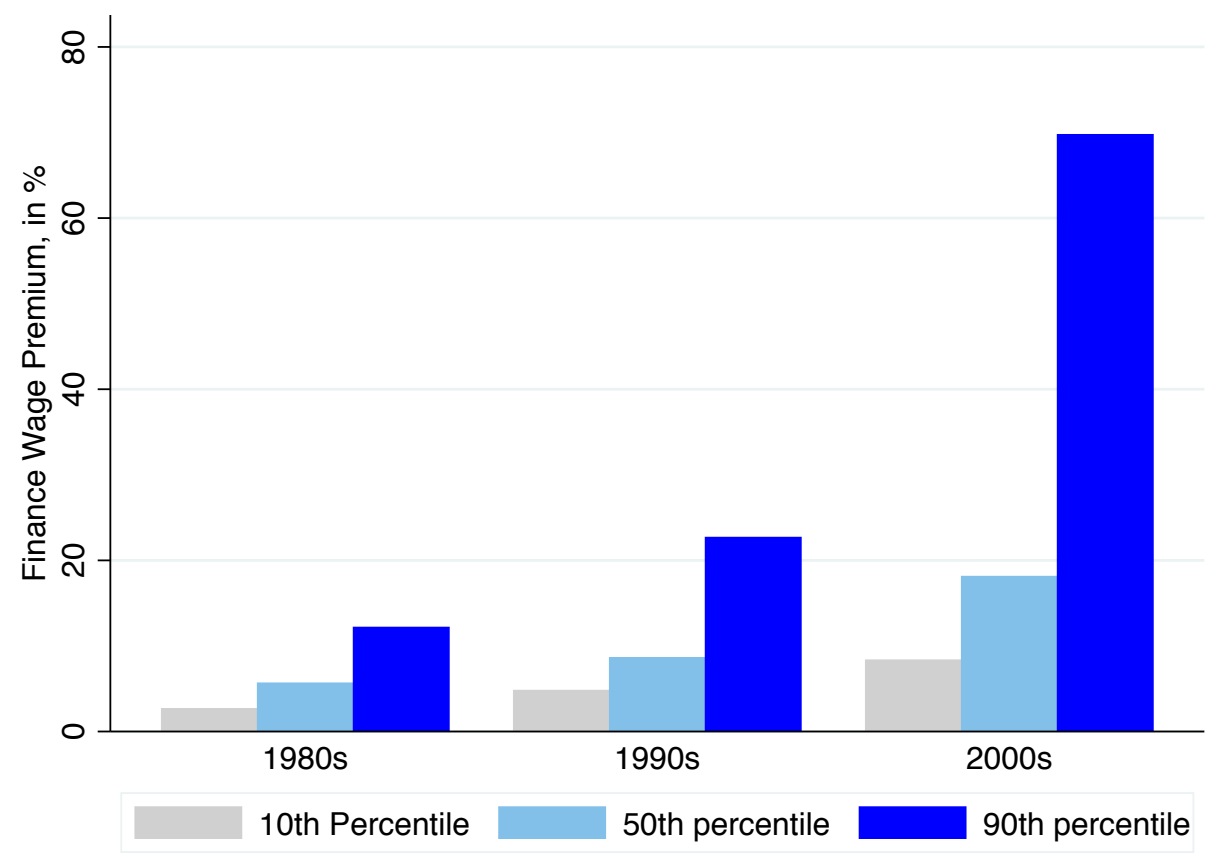

Figure 4. Evolution of the Finance Wage Premium by Percentiles of the Wage Distribution

Note: The graph plots the evolution of the coefficient of the financial sector dummy in quantile regressions estimated at the 10th, 50th, and 90th percentiles of the wage distribution, in which the dependent variable is the log of the yearly gross wage. There are 48 industry dummies, and the estimation is constrained such that the sum of all industry dummy coefficients is zero. Each regression also controls for education, gender, marital status, occupation, firm type, firm size, hierarchical responsibilities, working abroad, working in the Paris area, experience, experience squared, and experience cubed. 


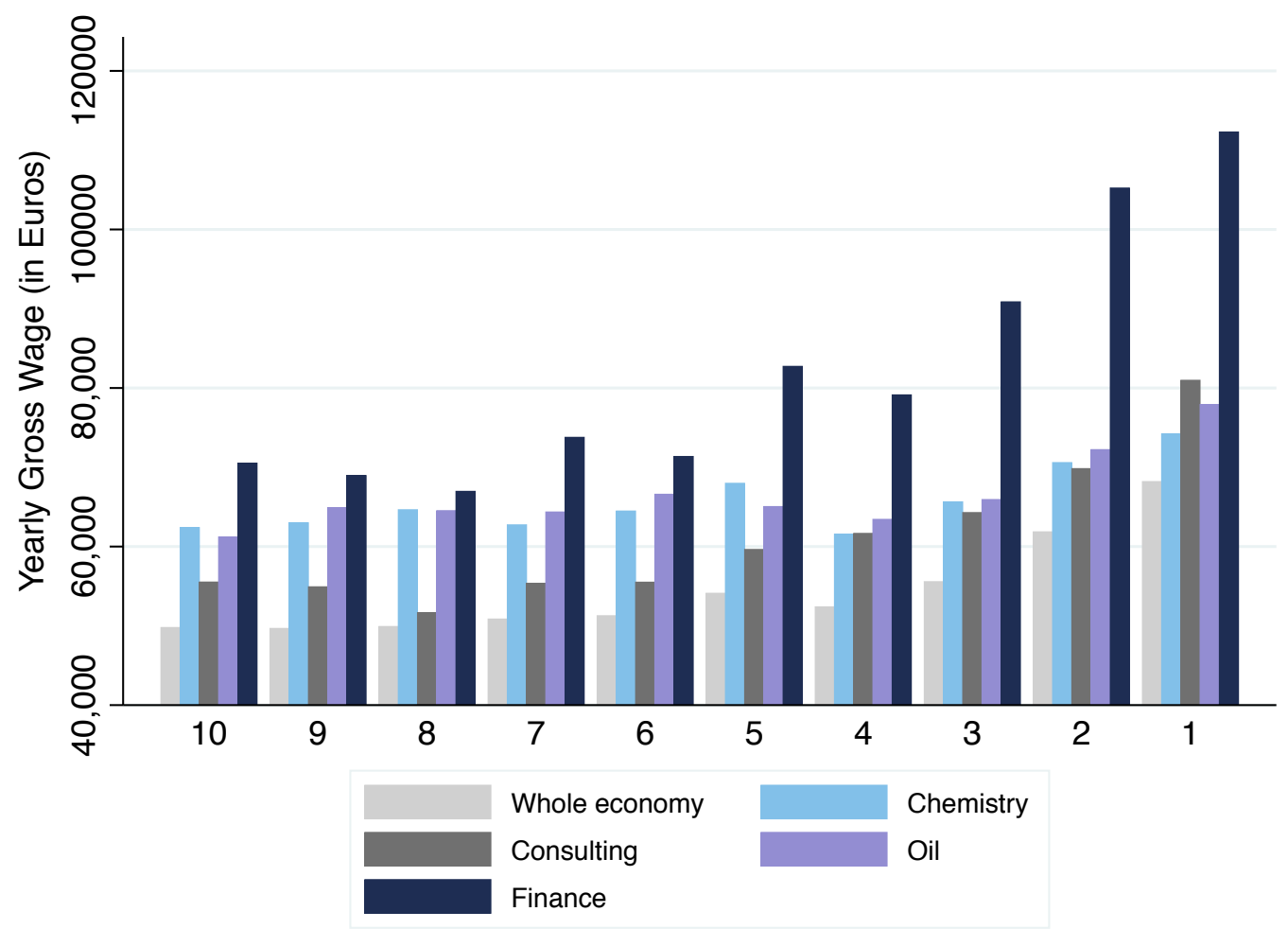

Figure 5. Predicted Wage over School Rank and Sectors

Note: This graph displays the predicted yearly gross wage calculated from the estimation of an OLS regression at fixed value of School Rank and averaged over all other variables. The dependent variable is the log of the yearly gross wage, the estimation period, 2004-2011. The regression is estimated over five samples: the whole economy (124,433 observations), and the chemistry (2,752 observations), oil (717 observations), consulting (3,773 observations), and finance (3,431 observations) industries. The model includes a female dummy, a married dummy, a female $\times$ married dummy, a Paris area dummy, eight education dummies, a working abroad dummy, six country dummies, experience level squared and cubed, four hierarchic responsibility dummies, nine occupation dummies, four firm size dummies, and four firm type dummies. 


\section{B Tables}

Table 1. Summary Statistics

\begin{tabular}{|c|c|c|c|}
\hline & $1980 \mathrm{~s}$ & $1990 \mathrm{~s}$ & $2000 \mathrm{~s}$ \\
\hline \multicolumn{4}{|l|}{ Sample Size } \\
\hline Average number of observations per survey & 20,805 & 15,088 & 17,776 \\
\hline Number of Surveys & 3 & 4 & 7 \\
\hline Total number of observations & 62,415 & 60,353 & 124,433 \\
\hline Response rate (\%) & 21 & 17 & $\mathrm{Nd}$ \\
\hline Coverage of total population of French engineers (\%) & 9 & 7.1 & 6.2 \\
\hline \multicolumn{4}{|l|}{ Compensation (in 2005 constant euros) } \\
\hline Mean yearly gross wage & 62,137 & 62,625 & 57,983 \\
\hline $90^{\text {th }}$ centile & 99,718 & 101,964 & 95,598 \\
\hline $99^{\text {th }}$ centile & 146,253 & 169,870 & 186,438 \\
\hline Standard deviation & 27,073 & 31,827 & 39,086 \\
\hline \multicolumn{4}{|l|}{ Engineers per sector (in \%) } \\
\hline Finance & 1.9 & 2.3 & 3.5 \\
\hline Consulting & 0.0 & 1.5 & 3.6 \\
\hline Oil & 3.1 & 1.8 & 0.7 \\
\hline Chemistry & 3.6 & 3.8 & 2.6 \\
\hline \multicolumn{4}{|l|}{ Demographics } \\
\hline Mean age & 38.4 & 38.2 & 35.1 \\
\hline Percent female & 6.1 & 11.9 & 15.3 \\
\hline Percent married & 77.7 & 73.6 & 77.2 \\
\hline \multicolumn{4}{|l|}{ Work location } \\
\hline Percent working outside France & 2.6 & 4.1 & 12.1 \\
\hline Percent working in Paris area & 46.9 & 42.4 & 39.3 \\
\hline \multicolumn{4}{|l|}{ Career } \\
\hline Mean experience (in years) & 14.6 & 13.6 & 11.9 \\
\hline Percent team manager & 32.1 & 25.2 & 21.4 \\
\hline Percent department head & 15.9 & 19.2 & 17.7 \\
\hline Percent top executive & 6.5 & 11.3 & 7.1 \\
\hline
\end{tabular}

This table reports summary statistics for the main wage and demographic variables in our sample. 1980s $=$ graduates from the 1983, 1986, and 1989 surveys; 1990s = graduates from the 1992, 1995, 1998, and 2000 surveys; 2000 s $=$ graduates from the 2004, 2005, 2006, 2007, 2008, 2010, and 2011 surveys. Source: IESF Compensation Survey. 
Table 2. Measuring Talent

\begin{tabular}{|c|c|c|c|c|c|c|c|}
\hline \multirow{2}{*}{$\begin{array}{l}\text { School } \\
\text { Rank } \\
\text { (1) }\end{array}$} & \multirow{2}{*}{$\begin{array}{l}\text { Recruitment } \\
\text { Level } \\
(2)\end{array}$} & \multirow{2}{*}{$\begin{array}{l}\# \\
\text { Schools } \\
(3)\end{array}$} & \multicolumn{2}{|c|}{ Graduates } & \multirow{2}{*}{$\begin{array}{l}2011 \\
\text { Wage } \\
(6)\end{array}$} & \multirow{2}{*}{$\begin{array}{l}\% \text { Top } \\
\text { Manager } \\
(7)\end{array}$} & \multirow{2}{*}{$\begin{array}{l}\% \text { Early } \\
\text { Graduation } \\
\text { (8) }\end{array}$} \\
\hline & & & $\begin{array}{l}\text { Number } \\
\text { (4) }\end{array}$ & $\begin{array}{l}\% \text { Share } \\
(5)\end{array}$ & & & \\
\hline 1 & Top $2 \%$ & 1 & 6,173 & 2.7 & 97,740 & 32.2 & 36.0 \\
\hline 2 & Top 5\% & 3 & 12,868 & 5.7 & 83,128 & 17.6 & 21.2 \\
\hline 3 & Top $10 \%$ & 5 & 16,983 & 7.5 & 67,811 & 10.5 & 14.8 \\
\hline 4 & Top $15 \%$ & 5 & 12,236 & 5.4 & 64,718 & 10.8 & 12.8 \\
\hline 5 & Top $30 \%$ & 7 & 12,182 & 5.4 & 66,576 & 15.5 & 17.1 \\
\hline 6 & Top $40 \%$ & 8 & 11,468 & 5.1 & 55,018 & 10.3 & 11.4 \\
\hline 7 & Top $50 \%$ & 14 & 46,676 & 20.6 & 59,279 & 9.7 & 13.0 \\
\hline 8 & Top $60 \%$ & 21 & 20,747 & 9.1 & 53,421 & 8.8 & 8.9 \\
\hline 9 & Top $80 \%$ & 45 & 36,615 & 16.1 & 51,698 & 9.7 & 11.2 \\
\hline 10 & $100 \%$ & 87 & 50,898 & 22.4 & 54,477 & 5.4 & 10.3 \\
\hline Total & - & 196 & 226,846 & 100.0 & 59,934 & - & - \\
\hline
\end{tabular}

This table reports summary statistics over our talent measure School Rank. This talent measure takes a value from 1 to 10 and sorts schools based on level of recruitment. French engineering schools, or "Grandes Ecoles", select students for admission based chiefly on national ranking in a competitive written and oral exam. Recruitment level (column (2)) is the position of the marginal student for each school in the national ranking. Columns (4) and (5) give the number and share of students for each level of talent. Column (6) is the average yearly gross wage in 2011 for each level of talent in 2005 constant euros. Column (7) is the share of respondents leading a department or more, after 20 years of experience. Column (8) reports the share of respondents that graduates early (at least one year ahead). 
Table 3. Heterogenous Wage Returns to Talent across Industries

\begin{tabular}{|c|c|c|c|c|c|}
\hline \multirow{4}{*}{ Talent Measure } & \multicolumn{5}{|c|}{ Log(Wage) } \\
\hline & \multicolumn{3}{|c|}{ OLS } & \multirow{2}{*}{\multicolumn{2}{|c|}{$\frac{\text { Pseudo-Panel }}{\text { 11-School Rank }}$}} \\
\hline & \multicolumn{2}{|c|}{ 11-School Rank } & \multirow{2}{*}{$\begin{array}{c}\text { Graduation Age } \\
\text { (\# Years Ahead) } \\
(3)\end{array}$} & & \\
\hline & (1) & (2) & & (4) & (5) \\
\hline Finance & $\begin{array}{c}0.247^{* * *} \\
(0.033)\end{array}$ & $\begin{array}{c}0.029 \\
(0.025)\end{array}$ & $\begin{array}{c}0.175^{* * *} \\
(0.039)\end{array}$ & $\begin{array}{c}0.255^{* * *} \\
(0.075)\end{array}$ & $\begin{array}{l}-0.009 \\
(0.112)\end{array}$ \\
\hline Talent $\times$ Finance & & $\begin{array}{c}0.043^{* * *} \\
(0.006)\end{array}$ & $\begin{array}{l}0.039^{*} \\
(0.021)\end{array}$ & & $\begin{array}{c}0.056^{* *} \\
(0.024)\end{array}$ \\
\hline Consulting & $\begin{array}{c}0.138^{* * *} \\
(0.012)\end{array}$ & $\begin{array}{c}0.049^{* * *} \\
(0.017)\end{array}$ & $\begin{array}{c}0.041 \\
(0.029)\end{array}$ & $\begin{array}{c}0.074 \\
(0.057)\end{array}$ & $\begin{array}{c}0.076 \\
(0.091)\end{array}$ \\
\hline Talent $\times$ Consulting & & $\begin{array}{c}0.020^{* * *} \\
(0.003)\end{array}$ & $\begin{array}{c}0.019 \\
(0.015)\end{array}$ & & $\begin{array}{l}-0.000 \\
(0.021)\end{array}$ \\
\hline Oil & $\begin{array}{c}0.128^{* * *} \\
(0.010)\end{array}$ & $\begin{array}{c}0.160^{* * *} \\
(0.018)\end{array}$ & $\begin{array}{c}0.137^{* *} \\
(0.061)\end{array}$ & $\begin{array}{c}0.136 \\
(0.083)\end{array}$ & $\begin{array}{c}0.133 \\
(0.162)\end{array}$ \\
\hline Talent $\times$ Oil & & $\begin{array}{c}-0.006^{* *} \\
(0.003)\end{array}$ & $\begin{array}{c}0.003 \\
(0.017)\end{array}$ & & $\begin{array}{c}0.000 \\
(0.025)\end{array}$ \\
\hline Chemistry & $\begin{array}{c}0.073^{* * *} \\
(0.007)\end{array}$ & $\begin{array}{c}0.090^{* * *} \\
(0.010)\end{array}$ & $\begin{array}{c}0.050 \\
(0.032)\end{array}$ & $\begin{array}{l}0.104^{* *} \\
(0.049)\end{array}$ & $\begin{array}{c}0.088 \\
(0.091)\end{array}$ \\
\hline Talent $\times$ Chemistry & & $\begin{array}{c}-0.004^{* * *} \\
(0.002)\end{array}$ & $\begin{array}{c}0.003 \\
(0.013)\end{array}$ & & $\begin{array}{c}0.004 \\
(0.024)\end{array}$ \\
\hline Talent & $\begin{array}{c}0.021^{* * *} \\
(0.003)\end{array}$ & $\begin{array}{c}0.019^{* * *} \\
(0.003)\end{array}$ & $\begin{array}{c}0.025^{* * *} \\
(0.005)\end{array}$ & & \\
\hline Individual Fixed Effects & - & - & - & Yes & Yes \\
\hline School Fixed Effects & - & - & Yes & - & - \\
\hline Individual Controls & Yes & Yes & Yes & - & - \\
\hline Year Fixed Effects & Yes & Yes & Yes & Yes & Yes \\
\hline Observations & 198,886 & 198,886 & 52,332 & 62,715 & 62,715 \\
\hline$R^{2}$ & 0.698 & 0.701 & 0.548 & 0.949 & 0.950 \\
\hline
\end{tabular}

This table reports the coefficient of OLS regressions, where the dependent variable is the log of the yearly gross wage. The oil, finance, chemistry, and consulting industries have a dummy variable. Talent (which takes a value from 1 to 10) is equal to 11-School Rank, with School Rank based on the ranking of the marginal student in the national competitive exam, as defined in table 2. All equations include year dummies, a female dummy, a married dummy, a female $\times$ married dummy, a Paris area dummy, a working abroad dummy, experience level squared and cubed, four hierarchic responsibility dummies, nine occupation dummies, four firm size dummies, and four firm type dummies. Standard errors are clustered at the school level and reported in brackets, ${ }^{*} \mathrm{p}<0.10,{ }^{* *} \mathrm{p}<0.05,{ }^{* * *} \mathrm{p}<0.01$. 
Table 4. Increasing Wage Returns to Talent in the Finance Industry

\begin{tabular}{lccc}
\hline & \multicolumn{3}{c}{ Log(Wage) } \\
\cline { 2 - 4 } & S1980 & S1990 & S2000 \\
& $(1)$ & $(2)$ & $(3)$ \\
\hline Finance & 0.010 & 0.015 & 0.026 \\
Talent $\times$ Finance & $(0.022)$ & $(0.026)$ & $(0.026)$ \\
Talent & $0.011^{* *}$ & $0.023^{* * *}$ & $0.055^{* * *}$ \\
& $(0.004)$ & $(0.004)$ & $(0.005)$ \\
Individual Controls & $0.017^{* * *}$ & $0.019^{* * *}$ & $0.020^{* * *}$ \\
Year Fixed Effects & $(0.002)$ & $(0.003)$ & $(0.003)$ \\
Observations & Yes & Yes & Yes \\
$R^{2}$ & 41,731 & Yes & Yes \\
\hline
\end{tabular}

This table reports the coefficient of a standard OLS regression over three samples: S1980 = the 1986 and 1989 surveys (Column (1)); S1990 = 1992, 1995, 1998, and 2000 surveys (Column (2)); and S2000 = 2004, 2005, 2006, 2007, 2008, 2010, and 2011 surveys (Column (3)). The dependent variable is the log of the yearly gross wage. Talent (which takes a value from 1 to 10) is equal to 11-School Rank, with School Rank based on the ranking of the marginal student in the national competitive exam, as defined in table 2. All equations include year dummies, a female dummy, a married dummy, a female $\times$ married dummy, a Paris area dummy, a working abroad dummy, experience level squared and cubed, four hierarchic responsibility dummies, nine occupation dummies, four firm size dummies, and four firm type dummies. Standard errors are clustered at the school level and reported in brackets, ${ }^{*} \mathrm{p}<0.10,{ }^{* *} \mathrm{p}<0.05,{ }^{* * *} \mathrm{p}<0.01$. 
Table 5. Returns to Talent and Incentive Pay

\begin{tabular}{|c|c|c|c|c|}
\hline & \multicolumn{2}{|c|}{$\begin{array}{l}\text { Total Compensation } \\
\text { Log (wage) }\end{array}$} & \multicolumn{2}{|c|}{$\begin{array}{l}\text { Variable Compensation } \\
\log (1+\text { Share })\end{array}$} \\
\hline & (1) & (2) & $(3)$ & (4) \\
\hline Finance & $\begin{array}{c}0.203^{* * *} \\
(0.029)\end{array}$ & $\begin{array}{c}0.025 \\
(0.026)\end{array}$ & $\begin{array}{c}0.499^{* * *} \\
(0.052)\end{array}$ & $\begin{array}{c}0.165^{* * *} \\
(0.047)\end{array}$ \\
\hline Talent $\times$ Finance & & $\begin{array}{c}0.035^{* * *} \\
(0.004)\end{array}$ & & $\begin{array}{c}0.065^{* * *} \\
(0.007)\end{array}$ \\
\hline Talent & $\begin{array}{c}0.026^{* * *} \\
(0.003)\end{array}$ & $\begin{array}{c}0.024^{* * *} \\
(0.003)\end{array}$ & $\begin{array}{c}0.016^{* * *} \\
(0.004)\end{array}$ & $\begin{array}{c}0.012^{* * *} \\
(0.003)\end{array}$ \\
\hline Individual Controls & Yes & Yes & Yes & Yes \\
\hline Year Fixed Effects & Yes & Yes & Yes & Yes \\
\hline Observations & 52,777 & 52,777 & 52,777 & 52,777 \\
\hline $\mathrm{R}$ square & 0.447 & 0.450 & 0.144 & 0.147 \\
\hline
\end{tabular}

This table reports the coefficient of OLS regressions, where the dependent variable is the log of the yearly gross wage in columns (1) and (2), and of the share of variable compensation in columns (3) and (4). All equations include year dummies, a female dummy, a married dummy, a female $\times$ married dummy, a Paris area dummy, a working abroad dummy, experience level squared and cubed, four hierarchic responsibility dummies, nine occupation dummies, four firm size dummies, and four firm type dummies. Standard errors are clustered at the school level and reported in brackets, ${ }^{*} \mathrm{p}<0.10,{ }^{* *} \mathrm{p}<0.05,{ }^{* * *} \mathrm{p}<0.01$. 
Table 6. Robustness Checks

\begin{tabular}{|c|c|c|c|c|c|c|c|c|}
\hline \multirow{3}{*}{ Sample } & \multicolumn{8}{|c|}{ Log(Wage) } \\
\hline & \multicolumn{2}{|c|}{$\begin{array}{l}\text { Finance } \\
\text { Industry }\end{array}$} & \multirow{2}{*}{$\begin{array}{c}\text { Bottom } \\
\text { Schools } \\
\text { (3) }\end{array}$} & \multirow{2}{*}{$\begin{array}{c}\text { Middle } \\
\text { Schools } \\
\text { (4) }\end{array}$} & \multirow{2}{*}{$\begin{array}{c}\text { Top } \\
\text { Schools } \\
(5)\end{array}$} & \multirow{2}{*}{$\begin{array}{c}\text { No-X } \\
\text { Schools } \\
(6)\end{array}$} & \multicolumn{2}{|c|}{ All } \\
\hline & $(1)$ & $(2)$ & & & & & $(7)$ & (8) \\
\hline Talent & $\begin{array}{l}0.056^{* * *} \\
(0.006)\end{array}$ & $\begin{array}{l}0.049 * * * \\
(0.005)\end{array}$ & $\begin{array}{l}0.010^{*} \\
(0.005)\end{array}$ & $\begin{array}{l}0.001 \\
(0.011)\end{array}$ & $\begin{array}{l}0.068^{* * *} \\
(0.008)\end{array}$ & $\begin{array}{l}0.015^{* * *} \\
(0.003)\end{array}$ & $\begin{array}{l}0.018^{* * *} \\
(0.003)\end{array}$ & $\begin{array}{l}0.020^{* * *} \\
(0.003)\end{array}$ \\
\hline Talent $\times$ Finance & & & $\begin{array}{l}0.002 \\
(0.011)\end{array}$ & $\begin{array}{l}0.030 \\
(0.039)\end{array}$ & $\begin{array}{l}0.103^{* * *} \\
(0.015)\end{array}$ & $\begin{array}{l}0.038^{* * *} \\
(0.011)\end{array}$ & $\begin{array}{l}0.043^{* * *} \\
(0.005)\end{array}$ & $\begin{array}{l}0.033^{* * *} \\
(0.005)\end{array}$ \\
\hline Talent $\times$ Finance $\times$ Abroad & & & & & & & & $\begin{array}{l}0.025^{* * *} \\
(0.006)\end{array}$ \\
\hline Finance & & & $\begin{array}{l}0.136^{* * *} \\
(0.029)\end{array}$ & $\begin{array}{l}0.132 \\
(0.091)\end{array}$ & $\begin{array}{l}0.232^{* * *} \\
(0.039)\end{array}$ & $\begin{array}{l}0.053 \\
(0.032)\end{array}$ & $\begin{array}{l}0.023 \\
(0.031)\end{array}$ & $\begin{array}{l}-0.013 \\
(0.022)\end{array}$ \\
\hline Network Size & & & & & & & $\begin{array}{l}0.014 \\
(0.012)\end{array}$ & $\begin{array}{l}0.010 \\
(0.013)\end{array}$ \\
\hline Network Size $\times$ Finance & & & & & & & $\begin{array}{l}0.016 \\
(0.039)\end{array}$ & \\
\hline Job Fixed Effects & - & Yes & - & - & - & - & - & - \\
\hline Individual Controls & Yes & Yes & Yes & Yes & Yes & Yes & Yes & Yes \\
\hline Year Fixed Effects & Yes & Yes & Yes & Yes & Yes & Yes & Yes & Yes \\
\hline Observations & 2,428 & 2,428 & 141,755 & 32,985 & 33,026 & 178,377 & 195,243 & 195,243 \\
\hline$R^{2}$ & 0.557 & 0.614 & 0.685 & 0.699 & 0.686 & 0.693 & 0.701 & 0.700 \\
\hline
\end{tabular}

This table reports the coefficient of OLS regressions, where the dependent variable is the log of the yearly gross wage. In columns (1) and (2) the sample is restricted to individuals working in the finance industry in years 2006, 2007, 2008 and 2010. The survey provides the title of the job of each finance workers at these years (see the online appendix for summary statistics). In columns (3) to (5), engineering schools are grouped into three categories: the top group gathers the schools from rank 1 to 3 , the middle group schools from rank 4-6, and the bottom group the remaining schools. In column (6) the sample is restricted to all non related to Polytechnique schools. In columns (7) and (8) we proxy the size of the network by the total number of students in each school. All equations include year dummies, a female dummy, a married dummy, a female $\times$ married dummy, a Paris area dummy, a working abroad dummy, experience level squared and cubed, four hierarchic responsibility dummies, nine occupation dummies, four firm size dummies, and four firm type dummies. Standard errors are clustered at the school level and reported in brackets, ${ }^{*} \mathrm{p}<0.10,{ }^{* *} \mathrm{p}<0.05,{ }^{* * *} \mathrm{p}<0.01$. 


\section{Appendix A - List of Variables}

Selection rate: the ratio of the rank of the last admitted candidate to the total number of applicants. See online appendix for more details on this coding.

Graduation age: the age at which a student obtains the "Engineer" degree; in France, a student who has neither skipped nor repeated a year of schooling usually graduates at 23 years of age.

Predicted wage: the wage obtained when predicting wages using the coefficients of the main equation.

Early graduation: an indicator variable for graduating earlier than the standard age (23 years old).

Top manager: an indicator variable for holding a top management position, defined in the survey by being on the executive committee.

Finance: an indicator variable for working in the financial sector, which includes banks, investment funds, and insurance companies.

Wage: the gross annual salary of a given engineer, as disclosed in the alumni survey.

Variable compensation: the annual amount of variable compensation, disclosed in a specific question on the survey.

Job title: the exact occupation within finance (e.g., trader, risk manager, investment banker).

Bottom schools: the schools from the lower tier of the selectivity scale (categories 7 to 9).

Middle schools: the schools from the middle tier of the selectivity scale (categories 4 to 6).

Top schools: the schools from the top tier of the selectivity scale (categories 1 to 3 ).

Abroad: an indicator variable for working outside of France.

Network size: the number of alumni of a given school, proxied by the annual number of graduates.

School rank: the level of selectivity of a given engineering school within ten categories (see table A3 in the appendix for the list of schools by level of selectivity).

$X$-schools: schools affiliated with the top French engineering school, Ecole Polytechnique. 


\section{Appendix B - Figures}

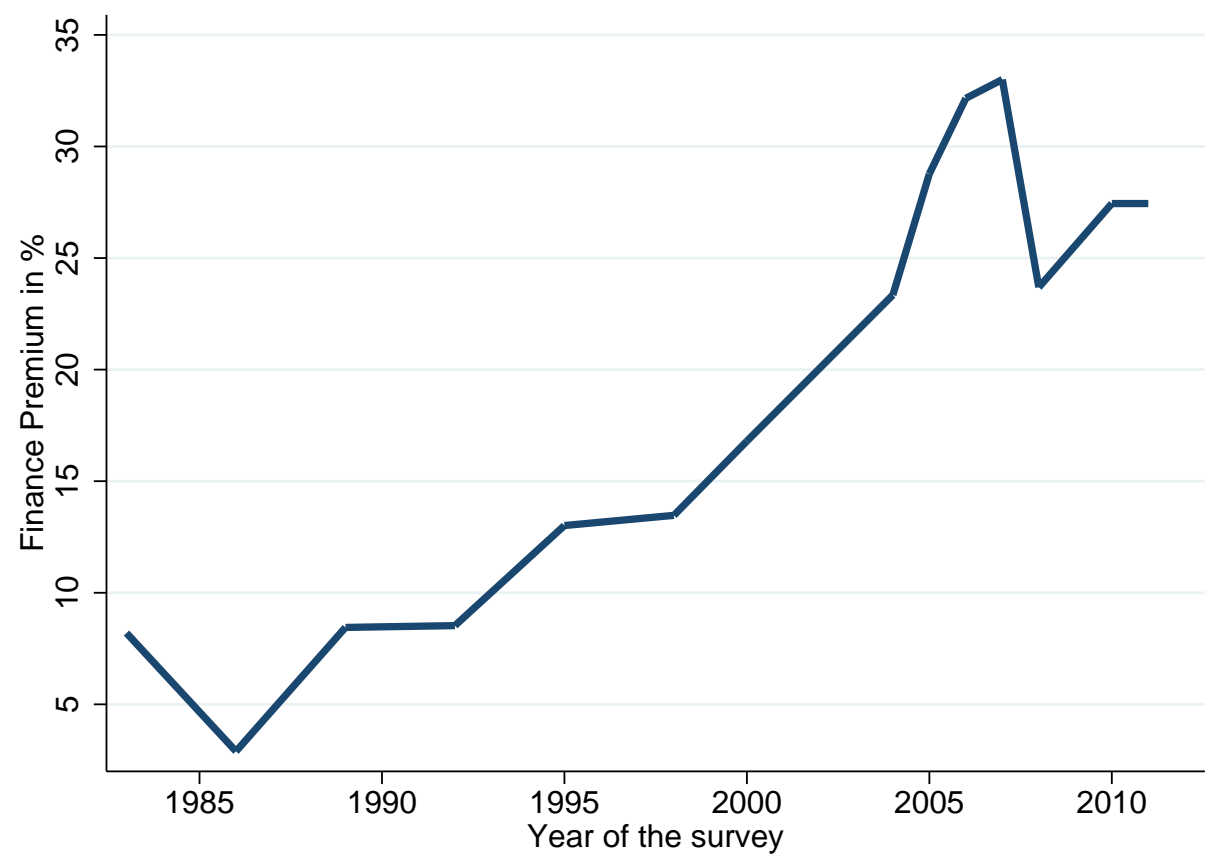

Figure 1. The Finance Wage Premium Evolution

Note: The graph displays the evolution of the coefficient of the financial sector dummy in OLS regressions estimated over the 1983-2011 period (247,201 observations), in which the dependent variable is the log of the yearly gross wage. All equations include year dummies, a female dummy, a married dummy, a female $\times$ married dummy, a Paris area dummy, a working abroad dummy, experience level squared and cubed, four hierarchic responsibility dummies, nine occupation dummies, four firm size dummies, and four firm type dummies. 


\section{Appendix C - Tables}

Table A1. Standard Determinants of Wages (Controls)

\begin{tabular}{|c|c|}
\hline & $\begin{array}{c}\log (\text { Wage }) \\
\text { (1) }\end{array}$ \\
\hline Female & $\begin{array}{c}-0.069 * * * \\
(0.002)\end{array}$ \\
\hline Age & $\begin{array}{c}0.008^{* * *} \\
(0.000)\end{array}$ \\
\hline Married & $\begin{array}{c}0.033^{* * *} \\
(0.001)\end{array}$ \\
\hline Experience (years) & $\begin{array}{c}0.056^{* * *} \\
(0.001)\end{array}$ \\
\hline Experience $^{2}$ & $\begin{array}{c}-0.002^{* * *} \\
(0.000)\end{array}$ \\
\hline Experience $^{3}$ & $\begin{array}{c}0.000^{* * *} \\
(0.000)\end{array}$ \\
\hline Paris Area & $\begin{array}{c}0.109 * * * \\
(0.001)\end{array}$ \\
\hline Outside France & $\begin{array}{c}0.318^{* * *} \\
(0.002)\end{array}$ \\
\hline Talent & $\begin{array}{c}0.029 * * * \\
(0.000)\end{array}$ \\
\hline Hierarchical Responsabilities: Team Manager & $\begin{array}{c}0.072^{* * *} \\
(0.001)\end{array}$ \\
\hline Hierarchical Responsabilities: Department Head & $\begin{array}{c}0.198^{* * *} \\
(0.002)\end{array}$ \\
\hline Hierarchical Responsabilities: Top Executive & $\begin{array}{c}0.315^{* * *} \\
(0.003)\end{array}$ \\
\hline Occupation: Production & $\begin{array}{c}0.001 \\
(0.002)\end{array}$ \\
\hline Occupation: IT & $\begin{array}{c}-0.009 * * * \\
(0.002)\end{array}$ \\
\hline Occupation: Sales & $\begin{array}{c}0.066^{* * *} \\
(0.002)\end{array}$ \\
\hline Occupation: Office Work & $\begin{array}{c}0.106^{* * *} \\
(0.003)\end{array}$ \\
\hline Occupation: Head Office & $\begin{array}{c}0.151^{* * *} \\
(0.004)\end{array}$ \\
\hline Firm Size: 20 to 500 employees & $\begin{array}{c}0.085^{* * *} \\
(0.002)\end{array}$ \\
\hline Firm Size: 500 to 2000 employees & $\begin{array}{c}0.129^{* * *} \\
(0.003)\end{array}$ \\
\hline Firm Size: >2000 employees & $\begin{array}{c}0.159^{* * *} \\
(0.002)\end{array}$ \\
\hline Firm Type: Private Sector & $\begin{array}{c}0.064^{* * *} \\
(0.004)\end{array}$ \\
\hline Firm Type: State Firm & $\begin{array}{c}0.017^{* * *} \\
(0.004)\end{array}$ \\
\hline Firm Type: Administration & $\begin{array}{c}-0.177^{* * *} \\
(0.005)\end{array}$ \\
\hline Firm Type: Other & $\begin{array}{c}-0.085^{* * *} \\
(0.008)\end{array}$ \\
\hline Year Fixed Effects & Yes \\
\hline Observations & 194,462 \\
\hline$R^{2}$ & 0.693 \\
\hline
\end{tabular}

This table reports coefficients of OLS regressions over the total sample. The dependent variable is the log of the yearly gross wage. The explanatory variables include all the controls used in the paper. 
Table A2. The Finance Premia

\begin{tabular}{|c|c|c|c|c|}
\hline & $\begin{array}{c}\text { MEAN } \\
(1)\end{array}$ & $\begin{array}{c}10^{\mathrm{TH}} \\
(2)\end{array}$ & $\begin{array}{c}50^{\mathrm{TH}} \\
(3)\end{array}$ & $\begin{array}{c}90^{\mathrm{TH}} \\
(4)\end{array}$ \\
\hline 1983 Premia & $\begin{array}{c}0.080 \\
(0.014)\end{array}$ & $\begin{array}{c}0.022 \\
(0.022)\end{array}$ & $\begin{array}{c}0.057 \\
(0.013)\end{array}$ & $\begin{array}{c}0.091 \\
(0.022)\end{array}$ \\
\hline 1986 Premia & $\begin{array}{c}0.032 \\
(0.011)\end{array}$ & $\begin{array}{c}-0.002 \\
(0.019)\end{array}$ & $\begin{array}{c}0.029 \\
(0.012)\end{array}$ & $\begin{array}{c}0.029 \\
(0.019)\end{array}$ \\
\hline 1989 Premia & $\begin{array}{c}0.090 \\
(0.011)\end{array}$ & $\begin{array}{c}0.034 \\
(0.017)\end{array}$ & $\begin{array}{c}0.072 \\
(0.012)\end{array}$ & $\begin{array}{c}0.141 \\
(0.016)\end{array}$ \\
\hline 1992 Premia & $\begin{array}{c}0.086 \\
(0.012)\end{array}$ & $\begin{array}{c}0.045 \\
(0.021)\end{array}$ & $\begin{array}{c}0.058 \\
(0.010)\end{array}$ & $\begin{array}{c}0.081 \\
(0.012)\end{array}$ \\
\hline 1995 Premia & $\begin{array}{c}0.120 \\
(0.017)\end{array}$ & $\begin{array}{c}0.050 \\
(0.033)\end{array}$ & $\begin{array}{c}0.090 \\
(0.015)\end{array}$ & $\begin{array}{c}0.177 \\
(0.025)\end{array}$ \\
\hline 1998 Premia & $\begin{array}{c}0.131 \\
(0.013)\end{array}$ & $\begin{array}{c}0.035 \\
(0.018)\end{array}$ & $\begin{array}{c}0.074 \\
(0.013)\end{array}$ & $\begin{array}{c}0.169 \\
(0.022)\end{array}$ \\
\hline 2000 Premia & $\begin{array}{c}0.163 \\
(0.014)\end{array}$ & $\begin{array}{c}0.021 \\
(0.019)\end{array}$ & $\begin{array}{c}0.076 \\
(0.012)\end{array}$ & $\begin{array}{c}0.344 \\
(0.026)\end{array}$ \\
\hline 2004 Premia & $\begin{array}{c}0.250 \\
(0.015)\end{array}$ & $\begin{array}{c}0.071 \\
(0.020)\end{array}$ & $\begin{array}{c}0.126 \\
(0.016)\end{array}$ & $\begin{array}{c}0.579 \\
(0.022)\end{array}$ \\
\hline 2005 Premia & $\begin{array}{c}0.272 \\
(0.013)\end{array}$ & $\begin{array}{c}0.053 \\
(0.018)\end{array}$ & $\begin{array}{c}0.173 \\
(0.012)\end{array}$ & $\begin{array}{c}0.589 \\
(0.019)\end{array}$ \\
\hline 2006 Premia & $\begin{array}{c}0.320 \\
(0.011)\end{array}$ & $\begin{array}{c}0.082 \\
(0.015)\end{array}$ & $\begin{array}{c}0.163 \\
(0.009)\end{array}$ & $\begin{array}{c}0.740 \\
(0.017)\end{array}$ \\
\hline 2007 Premia & $\begin{array}{c}0.320 \\
(0.010)\end{array}$ & $\begin{array}{c}0.080 \\
(0.015)\end{array}$ & $\begin{array}{c}0.192 \\
(0.009)\end{array}$ & $\begin{array}{c}0.740 \\
(0.014)\end{array}$ \\
\hline 2008 Premia & $\begin{array}{c}0.231 \\
(0.011)\end{array}$ & $\begin{array}{c}0.068 \\
(0.015)\end{array}$ & $\begin{array}{c}0.125 \\
(0.010)\end{array}$ & $\begin{array}{c}0.479 \\
(0.018)\end{array}$ \\
\hline 2010 Premia & $\begin{array}{c}0.287 \\
(0.012)\end{array}$ & $\begin{array}{c}0.109 \\
(0.016)\end{array}$ & $\begin{array}{c}0.190 \\
(0.012)\end{array}$ & $\begin{array}{c}0.622 \\
(0.020)\end{array}$ \\
\hline 2011 Premia & $\begin{array}{c}0.301 \\
(0.014)\end{array}$ & $\begin{array}{c}0.096 \\
(0.017)\end{array}$ & $\begin{array}{c}0.219 \\
(0.011)\end{array}$ & $\begin{array}{c}0.655 \\
(0.019)\end{array}$ \\
\hline Trend Estimate & 1.109 & 0.329 & 0.659 & 2.837 \\
\hline
\end{tabular}

This table, which replicates Table 6 in Bell and Van Reenen (2010), reports coefficients of annual OLS (column (1)) and quantile regressions for $\mathrm{q}=0.1$ (column (2)), $\mathrm{q}=0.5$ (column (3)), and $\mathrm{q}=0.9$ (column (4)). The dependent variable is the log of the yearly gross wage. All equations include a female dummy, a married dummy, a female $\times$ married dummy, a Paris area dummy, school fixed effects, a working abroad dummy, experience level squared and cubed, four hierarchic responsibility dummies, nine occupation dummies, four firm size dummies, and four firm type dummies. Standard errors are clustered at the school level and reported in parentheses. Trend estimates are multiplied by 100 and adjusted by the number of years so as to be interpretable as the $\%$ relative annual wage increase for finance workers. 
Table A3: Engineering School List

\begin{tabular}{|c|c|c|c|c|}
\hline School Name & Rank & $\begin{array}{l}\text { Admission } \\
\text { Rate (\%) }\end{array}$ & $\begin{array}{c}\text { Baccalaureat } \\
\text { Grade (Post- } \\
\text { Bac Schools) }\end{array}$ & $\begin{array}{c}\text { Size } \\
\text { (\# students per year) }\end{array}$ \\
\hline Ecole Polytechnique & 1 & 1.5 & & 507 \\
\hline Mines Paristech & 2 & 2.5 & & 162 \\
\hline Centrale Paris & 2 & 4.6 & & 395 \\
\hline Ponts Paristech & 2 & 4.9 & & 252 \\
\hline Telecom Paristech & 3 & 8.1 & & 280 \\
\hline Supelec & 3 & 9.1 & & 538 \\
\hline Supaero (Isae) Toulouse & 3 & 9.3 & & 291 \\
\hline Ensta Paristech & 3 & 9.5 & & 140 \\
\hline Centrale Lyon & 3 & 9.9 & & 261 \\
\hline Centrale Lille & 4 & 10.2 & & 267 \\
\hline Ensae Paristech & 4 & 11.7 & & 150 \\
\hline Centrale Nantes & 4 & 11.8 & & 230 \\
\hline Centrale Marseille & 4 & 12.1 & & 139 \\
\hline Mines De Nancy & 4 & 14.4 & & 176 \\
\hline Mines De Saint-Etienne & 5 & 15.9 & & 172 \\
\hline Telecom Bretagne & 5 & 19.8 & & \\
\hline Chimie Paristech & 5 & 23.9 & & 89 \\
\hline Ensica (Isae) Toulouse & 5 & 24.8 & & 110 \\
\hline Grenoble Inp - Ensimag & 5 & 26.4 & & 155 \\
\hline Agroparistech Grignon & 5 & 28.5 & & \\
\hline Montpellier Sup Agro & 5 & 28.9 & & \\
\hline Ensc Montpellier & 6 & 31.4 & & 103 \\
\hline Grenoble Inp - Phelma & 6 & 33.1 & & 48 \\
\hline Enac Toulouse & 6 & 34.7 & & 119 \\
\hline Grenoble Inp - Ense3 & 6 & 35.2 & & 1089 \\
\hline Grenoble Inp - PhelmaElectronique & 6 & 37.5 & & 1089 \\
\hline Ensma Poitiers & 6 & 39.9 & & 161 \\
\hline Agrocampus Ouest & 6 & 40.0 & & 156 \\
\hline Enseeiht Toulouse Genie Electrique & 7 & 40.0 & & 371 \\
\hline Enseeiht Toulouse Electronique & 7 & 41.4 & & 126 \\
\hline Arts Et Metiers Paristech & 7 & 41.6 & & 1232 \\
\hline Ensat Toulouse & 7 & 44.3 & & 126 \\
\hline Ensc Lille & 7 & 46.7 & & 69 \\
\hline Enscbp Bordeaux - Chimie-Physique & 7 & 48.1 & & \\
\hline Ensea Cergy & 7 & 49.5 & & 188 \\
\hline Ensci Limoges & 7 & 49.8 & & 50 \\
\hline Ensi Poitiers Eau Et Genie & 7 & 50.0 & & \\
\hline Insa Rennes & 7 & & 16 & 257 \\
\hline Insa Rouen & 7 & & 16 & 238 \\
\hline Insa Lyon & 7 & & 16 & 883 \\
\hline Insa Strasbourg & 7 & & 16 & 187 \\
\hline Insa Toulouse & 7 & & 16 & 444 \\
\hline Supmeca Paris & 8 & 50.0 & & 200 \\
\hline Ensc Rennes & 8 & 52.4 & & 71 \\
\hline Ensta Bretagne (Ex Ensieta) & 8 & 52.6 & & 143 \\
\hline Ensaia Nancy & 8 & 53.2 & & 140 \\
\hline Engees Strasbourg (Apprenti) & 8 & 53.5 & & 80 \\
\hline Ensiacet Toulouse Genie Industriel & 8 & 53.8 & & 187 \\
\hline Ensicaen Informatique & 8 & 53.9 & & 205 \\
\hline Enseirb-Matmeca Bordeaux Electronique & 8 & 54.1 & & 207 \\
\hline Ensic Nancy & 8 & 56.2 & & 107 \\
\hline Ensmm Besancon & 8 & 56.8 & & 167 \\
\hline Ensem Nancy & 8 & 57.6 & & 122 \\
\hline Enitab Bordeaux (Civil) & 8 & 58.0 & & 112 \\
\hline
\end{tabular}


Table A3 - continued from previous page

\begin{tabular}{lccc}
\hline School Name & Rank & $\begin{array}{c}\text { Admission } \\
\text { Rate (\%) }\end{array}$ & $\begin{array}{c}\text { Baccalaureat } \\
\text { Grade (Post- } \\
\text { Bac Schools) }\end{array}$
\end{tabular}$\quad$ (\# students per year)

Eost Strasbourg

58.3

Cpe Lyon Electronique

58.4

Ensp Strasbourg

59.1

251
77

Ensil Limoges Ee

59.4

251
77

Enesad Dijon

Utc Compiegne

Union Des Insa (2000)

Inp Toulouse

Isima Clermont-Ferrand

Ensiame Valenciennes Meca Energ.

Ensg Nancy

Ecpm Strasbourg

Ensc Mulhouse

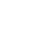

Entpe Vaulx En Velin

Eivp Paris

Esial Nancy

Telecom St Etienne

Enssat Lannion

Telecom Sudparis - Cursus Evry

Vetagro Sup Clermont-Ferrand (Civil)

Agrosup Dijon

Ecole Des Mines Nantes

Estp Paris Topographie

Polytech Lille

Ecole Des Mines Douai

Ecole Des Mines D'Ales

Polytech Nantes

Ecole Des Mines D'Albi

Enstib Epinal

Polytech Paris-Upmc

Polytech Nice

Isat Nevers

Esil Marseille Biomedical

Inpl Nancy

Ensccf Clermont-Ferrand

Enise Saint-Etienne

Eivl Blois

Groupe

Polytech Marseille

Epf Sceaux

Ifma Clermont-Ferrand

Grenoble Inp

Polytech Grenoble

Estaca Levallois-Perret

Ist Bretagne

Telecom Lille1

Ensgsi Nancy

Polytech'Montpellier

Enitiaa Nantes

Eisti Cergy-Pontoise

Insa Val De Loire

Ensg Marne La Vallee

Utt Troyes

Espci Paristech

$\begin{array}{ll}8 & 58 \\ 8 & 59 \\ 8 & 59 \\ 8 & \end{array}$

15

83

15

15

15

626

60.0

60.0

60.0

60.2

61.1

65.4

65.9

66.4

66.7

67.1

67.6

68.4

69.6

69.8

69.9

72.0

72.2

73.2

73.8

74.1

74.5

75.8

76.0

77.0

79.6

146

122

92

84

63

204

84

91

170

109

77

138

503

228

162

158

243

48

64

123

71

84

63

135

83

276

114

202

135

1089

176

276

156

64

232

84

104

14

297

80.2

70 
Table A3 - continued from previous page

\begin{tabular}{|c|c|c|c|c|}
\hline School Name & Rank & $\begin{array}{l}\text { Admission } \\
\text { Rate }(\%)\end{array}$ & $\begin{array}{c}\text { Baccalaureat } \\
\text { Grade (Post- } \\
\text { Bac Schools) }\end{array}$ & $\begin{array}{c}\text { Size } \\
\text { (\# students per year) }\end{array}$ \\
\hline Polytech Orleans & 10 & 80.2 & & 176 \\
\hline Esstin Nancy & 10 & 81.2 & & 133 \\
\hline Esmisab Brest & 10 & 81.5 & & \\
\hline Polytech Tours & 10 & 81.8 & & 124 \\
\hline Esirem Dijon Info-Elec. & 10 & 82.7 & & \\
\hline Polytech Clermont-Ferrand & 10 & 82.7 & & 159 \\
\hline Ensc Bordeaux & 10 & 82.7 & & 79 \\
\hline Ensim Le Mans & 10 & 82.7 & & \\
\hline Istil Epu Lyon 1 & 10 & 82.7 & & 91 \\
\hline Sup Galilee Villetaneuse & 10 & 82.7 & & \\
\hline Isty Versailles & 10 & 82.7 & & \\
\hline Lasalle Beauvais & 10 & 83.1 & & 267 \\
\hline Isen Brest & 10 & 84.4 & & 242 \\
\hline Isep Paris & 10 & 85.6 & & 150 \\
\hline Escom Compiegne & 10 & 85.8 & & 76 \\
\hline Hei & 10 & 85.9 & & 157 \\
\hline Ensisa Mulhouse Informatique Et Reseaux & 10 & 86.4 & & \\
\hline Ensisa Mulhouse Textile Et Fibres & 10 & 86.6 & & \\
\hline Eseo Angers & 10 & 87.1 & & 276 \\
\hline Institut D'Optique Graduate School & 10 & 87.3 & & 70 \\
\hline Ece Paris & 10 & 87.9 & & 233 \\
\hline Ensiie Evry & 10 & 88.0 & & 97 \\
\hline Eigsi & 10 & 88.9 & & 128 \\
\hline Ecam Lyon & 10 & 89.8 & & 114 \\
\hline Ensait Roubaix & 10 & 92.6 & & 80 \\
\hline Esigelec Rouen & 10 & 94.5 & & 264 \\
\hline Esme Sudria Ivry Sur Seine & 10 & 95.0 & & 225 \\
\hline Esb Nantes & 10 & 96.0 & & \\
\hline Efrei Paris & 10 & 96.6 & & 330 \\
\hline Esiee Amiens & 10 & 97.0 & & 212 \\
\hline Esigetel Fontainebleau & 10 & 97.6 & & 64 \\
\hline Ei-Ispa Alencon & 10 & 98.2 & & \\
\hline 3Il Limoges & 10 & 98.5 & & \\
\hline Grenoble Inp - Genie Industriel & 10 & 100.0 & & \\
\hline Enit Tarbes & 10 & & 13 & 92 \\
\hline Ebi Cergy & 10 & & 13 & 98 \\
\hline Ecam Rennes & 10 & & 13 & \\
\hline Ensgti Pau & 10 & & 13 & 55 \\
\hline Esilv La Defense & 10 & & 13 & \\
\hline Esiea Paris & 10 & & 13 & 260 \\
\hline Polytech Paris Sud & 10 & & 13 & \\
\hline Enim Metz & 10 & & 13 & 165 \\
\hline Dpe & 10 & & 12 & \\
\hline Itii Aquitaine Mecanique & 10 & & 12 & \\
\hline Isara Lyon & 10 & & 12 & 128 \\
\hline Itam & 10 & & 12 & \\
\hline Isa Angers & 10 & & 12 & 160 \\
\hline Itii Centre Production Polytech'Orleans & 10 & & 12 & \\
\hline Isa Lille & 10 & & 12 & 129 \\
\hline Eme Ker Lann & 10 & & 12 & \\
\hline Isiv & 10 & & 12 & \\
\hline Itech Lyon & 10 & & 12 & 111 \\
\hline Itii Alsace Mecanique Insa Strasbourg & 10 & & 12 & \\
\hline Esitapa Val De Reuil & 10 & & 12 & 96 \\
\hline
\end{tabular}


Table A3 - continued from previous page

\begin{tabular}{|c|c|c|c|c|}
\hline School Name & Rank & $\begin{array}{c}\text { Admission } \\
\text { Rate (\%) }\end{array}$ & $\begin{array}{c}\text { Baccalaureat } \\
\text { Grade (Post- } \\
\text { Bac Schools) }\end{array}$ & $\begin{array}{c}\text { Size } \\
\text { (\# students per year) }\end{array}$ \\
\hline Itiape Lille & 10 & & 12 & \\
\hline Itii Champagne-Ardenne Mecanique Ensam & 10 & & 12 & \\
\hline Fip & 10 & & 12 & \\
\hline Istimm & 10 & & 12 & \\
\hline Ingenieurs 2000 & 10 & & 12 & \\
\hline Esgt Le Mans & 10 & & 12 & 90 \\
\hline Utbm Belfort-Montbelliard & 10 & & 12 & 418 \\
\hline Cnam & 10 & & 12 & 91 \\
\hline Itii Picardie Mecanique Cnam & 10 & & 12 & \\
\hline Esite Epinal & 10 & & 12 & 96 \\
\hline Cefipa & 10 & & 12 & \\
\hline Itii Lyon Informatique & 10 & & 12 & \\
\hline Ifitep & 10 & & 12 & \\
\hline Ist Toulouse & 10 & & 12 & \\
\hline Itii Bass-Normandie Mecanique Ensicaen & 10 & & 12 & \\
\hline Itii Alsace Informatique Loire & 10 & & 12 & \\
\hline Igii Lens & 10 & & 12 & \\
\hline Ist Vendee Mecanique Et Automatique & 10 & & 12 & \\
\hline Fiti2A Quimper & 10 & & 12 & \\
\hline Isupfere & 10 & & 12 & \\
\hline Cesi & 10 & & 12 & 220 \\
\hline Itii Deux Savoies & 10 & & 12 & \\
\hline Ist Nord & 10 & & 12 & \\
\hline Itii Pays De Loire Btp & 10 & & 12 & \\
\hline Eia-Cesi & 10 & & 12 & \\
\hline Istp Ensme St Etienne & 10 & & 12 & \\
\hline Itii Hte-Normandie Mecanique & 10 & & 12 & \\
\hline Polytech Savoie & 10 & & 12 & \\
\hline Itii Pays De Loire Inform. Ind. Eseo & 10 & & 12 & \\
\hline Enspm Rueil-Malmaison & 10 & & 12 & 170 \\
\hline Itii Aquitaine Materiaux Enscpb & 10 & & 12 & \\
\hline Itii Pays De Loire & 10 & & 12 & \\
\hline Itii Aquitaine Prod. Maintenance & 10 & & 12 & \\
\hline Itii Bourgogne Genie Industriel & 10 & & 12 & \\
\hline Isel Le Havre & 10 & & 12 & \\
\hline
\end{tabular}

